\title{
Natural Law as Bedrock of Good Governance: Reflections on Alagbariya, Asimini and Halliday-Awusa as Selfless Monarchs towards Good Traditional Governance and Sustainable Community Development in Oil-rich Bonny Kingdom
}

\author{
Edward T. Bristol-Alagbariya * \\ Associate Dean \& Senior Multidisciplinary Lecturer, Faculty of Law, University of Port Harcourt, NIGERIA; \\ Affiliate Visiting Fellow, University of Aberdeen, UNITED KINGDOM; and Visiting Research Fellow, Centre \\ for Energy, Petroleum \& Mineral Law and Policy (CEPMLP), Graduate School of Natural Resources Law, \\ Policy \& Management, University of Dundee, Scotland, UNITED KINGDOM \\ *E-mail of the corresponding author: ebristolalagbariya@gmail.com
}

\begin{abstract}
Oil-rich Ancient Grand Bonny Kingdom, founded before or about 1,000AD, was the economic and political centre of the Ancient Niger Delta region and a significant symbol of African civilisation, before the creation of Opobo Kingdom out of it (in 1870) and the eventual evolution of modern Nigeria (in 1914). The people and houses of this oil-rich Kingdom of the Nigerian Delta region invest more in traditional rulership, based on house system of governance. The people rely more on their traditional rulers to foster their livelihoods and cater for their wellbeing and the overall good and prosperity of the Kingdom. Hence, there is a need for good traditional governance (GTG), more so, when the foundations of GTG and its characteristic features, based on natural law and natural rights, were firmly established during the era of the Kingdom's Premier Monarchs (Ndoli-Okpara, Opuamakuba, Alagbariya and Asimini), up to the reign of King Halliday-Awusa. Therefore, the aim of this socio-legal and divinely-based study is to sensitise and spur successive apex traditional rulers of the Kingdom, namely the Monarchs (Amanyanapu) and Country Chiefs (Se-Alapu) to promote and practise GTG, based on the ethical relationship between governance, government and service to the people, centred on truth, fair-play, publicspiritedness, responsible stewardship, integrity, hearkening to the voice or voices of reason and abiding by due process. The interrelated, intertwined and harmonious relationship of the past, through the present, to the future, embedded in the subject-matter and discipline of history, is thus important in the context of this study, as same promote the need for GTG, based on traditional government social responsibility (TGSR), premised on the relationship of natural law with good governance $(G G)$ established and nourished by Ancient Grand Bonny Kingdom's above-stated four Premier Monarchs, and thereafter sustained up to the era of King Halliday-Awusa, in the form of selfless leadership. Such a form and standard of traditional rulership would promote sustainable community development (SCD) in Bonny Kingdom. Finally, from the base and bedrock of divine natural law, the study recommends that an incumbent of the throne of kingship in Bonny should painstakingly promote and practise $T G S R$, ingrained in GTG, towards all-embracing advancement, prosperity and SCD of oil-rich and Christianised Ancient Grand Bonny Kingdom, in the ongoing worldwide era of globalisation, especially economic globalisation, $G G$ and $S D$.

Keywords: Natural Law; Natural Right; Bonny Kingdom; Amanyanapu (Monarchs/Kings); Founding Ancestors; Founding Fathers, Patriarchs and Premier Monarchs; Aseme (Royal Pedigree: Aboriginal Royal); Duawaris (Founding \& Aboriginal Royal Houses); Blood Descendants; Human Rights; Good Public Sector Governance (Good Governance [GG]); Good Traditional Governance (GTG); Traditional Government Social Responsibility (TGSR), Positive Law, Sustainable Community Development (SCD), Sustainable Development (SD); Wari (Ward, Lineage or House); House System.
\end{abstract}

DOI: $10.7176 / \mathrm{DCS} / 10-3-08$

Publication date:March $31^{\text {st }} 2020$

\section{Introduction}

This study covers the hereunder discussed sub-headings captioned 'Bonny Kingdom', 'Grand Bonny Kingdom: Its Origin, Cradle of its Civilisation and Common Heritage', and 'the House System, Houses and Successive Monarchs of the Kingdom'.

The house system of the Kingdom is the same as the ward or lineage system. This system is discussed as the core social system and pivot of life and society in the Kingdom, which was established by the Founding Ancestors of 
the Kingdom, and being consolidated upon and sustained by successive generations of the Kingdom. ${ }^{1}$ The foregoing sub-headings demonstrate that public sector governance was practised at the beginning of the Kingdom, within the rubrics of the house system, by the Founding Ancestors, led by the Founding Fathers, Patriarchs and Premier Monarchs of the Kingdom, namely Ndoli-Okpara, Opuamakuba, Alagbariya and Asimini. These subheadings also establish the importance of traditional rulership in the Kingdom, based on the house system, which evolved as the ward or lineage system. In effect, the ward, lineage or house system mean one and the same thing. ${ }^{2}$ The subheadings also underscore the importance of traditional rulership and hence the need for good traditional governance (GTG), based on traditional government social responsibility (TGSR) embedded in selfless public service and premised on the relationship of natural law to good governance (GG) established, nourished and sustained from the period of the Founding Fathers, Patriarchs and Premier Monarchs of the Kingdom to the era of their immediate successors, exemplified by the era of King Halliday-Awusa, towards GTG and sustainable community development (SCD) in oil-rich Ancient Grand Bonny Kingdom.

Given that the people and houses of Bonny Kingdom rely more on traditional rulers than constitutionally guaranteed civil governance in Nigeria and considering the interrelated, intertwined and harmonious relationship of the past, the present and future, embedded in the subject-matter and discipline of history, the aim of this sociolegal and divinely-based study is to sensitise and spur successive apex traditional rulers of the Kingdom to promote GTG. There is a need for these apex traditional rulers of oil-rich Bonny Kingdom, namely the Monarchs (Amanyanapu) and Country Chiefs (Se-Alapu) to promote, achieve, practise and sustain GTG, based on traditional government social responsibility (TGSR) inherent in natural law and its characteristic good governance features, ${ }^{3}$ such as love, truth, goodwill, fair-play, selfless public service, responsible stewardship, integrity, succumbing to the voice or voices of reason and abiding by due process, towards sustainable community development (SCD) in the Kingdom, in the ongoing worldwide era of globalisation, especially economic globalisation, good governance (GG), and sustainable development (SD).

\section{Bonny Kingdom}

Bonny Kingdom, also called Ancient Grand Bonny Kingdom and Grand Bonny Kingdom, is located forty kilometres southwards of Port Harcourt, the capital of Rivers State, Nigeria. It lies within latitude $40^{\circ} 278^{\circ}$, longitude $7^{0} 100^{\circ}$, on the shores of the Southern Atlantic Ocean into which its main River, the Bonny River, ultimately flows. ${ }^{4}$ The Bonny River is actually a major sea along the Atlantic coast of the Bonny area. The Kingdom is thus situated along the Atlantic coast of the eastern Delta, in the Bonny Local Government Area (OLGA) of Rivers State. Neighbouring areas to Bonny Kingdom include the Andoni (Obolo) Communities to the east, Kalabari Kingdom (New Calabar) to the north-west and the Okrika Kingdom to the north-east, while on the southern part of the Kingdom is its Atlantic coast called the 'Bight of Bonny', along a place called Rio Real (Rey del Rio), which is the name the Portuguese explorers and merchants called the Bonny area. ${ }^{5}$

In terms of natural geographic environmental features, Bonny Kingdom is located in a rain forest vegetation area, which is comprised of brackish mangrove forest vegetation at the banks of the Bonny River and its tributaries. The Kingdom's capital city, as well as the headquarters of OLGA, is Grand Bonny, which lies slightly above sea level. ${ }^{6}$ Grand Bonny (also variously called Grand Bonny City, Grand Bonny Island Community, Grand Bonny Island, Grand Bonny Island City and Bonny Island) is in the course of ongoing adverse effects of global warming, increasingly descending below sea level. By virtue of its geographical location and thus as a route to the outside world, Grand Bonny Island City occupies a very strategic position in the history of Bonny Kingdom and Nigeria at large. E. J. Alagoa and A. Fombo comment on the strategic location of Grand Bonny Island City in the following manner:

BONNY featured in the headlines of Nigerian newspapers, and appeared in the international press when, in July 1967, federal forces captured the [Bonny] port from the secessionists. It was an important event because this was

${ }^{1}$ E. J. Alagoa and A. Fombo, A Chronicle of Grand Bonny (Ibadan University Press 1972/Onyoma Research Publications 2001), 45, 49, 60-67.

${ }^{2}$ G. I. Jones, The Trading States of the Oil Rivers: A Study of Political Development in Eastern Nigeria (Oxford University Press 1963/James Currey Publishers 2000), 18, 51, 55 and 198, particularly 198.

${ }^{3}$ J. Budziszewski, Written on the Heart: The Case for Natural Law (InterVarsity Press 1997).

${ }^{4}$ Bonny Kingdom Historical Society, The History of Bonny (Bonny Kingdom Historical Society 2011), 20.

${ }^{5}$ E. J. Alagoa and A. Fombo (n1), 16, 45 and 76; K. E. Orji, 'The Place of Bonny in Niger Delta History' [2011] 5 (5) (22) African Research Review, 36-45; Bight of Bonny Act, No. 4 of 1975, Cap 34 Laws of the Federation of Nigeria (LFN) 1990, Cap B7 LFN 2004.

${ }^{6}$ E. T. Bristol-Alagbariya, Participation in Petroleum Development: Towards Sustainable Community Development in the Niger Delta (Centre for Energy, Petroleum \& Mineral Law \& Policy [CEPMLP]/Dundee University Press [DUP] 2010), 105110 . 
the first time successful major amphibian operation conducted by an independent African nation in modern times. Furthermore, Bonny was the main oil terminal port of Nigeria. By taking it, the Federal Government deprived the secessionists of any immediate international advantage they hoped to derive from control of oil areas. In addition, Bonny commands the entrance to the [Bonny] river through which the secessionists hoped to land military supplies at the only modern port in their control at Port Harcourt. The capture of Bonny was a further knot tightened in the military and economic blockade of the secessionists. To many local people, however, the event was significant because Bonny became the first place in the new Rivers State to be liberated by the forces of national unity.

The city of Bonny has been prominent in Nigerian history from the very early times. When the Portuguese first arrived on the Nigerian coast in the late $15^{\text {th }}$ Century, Bonny was their main seat of operations in the Eastern part of Nigeria, together with Elem Kalabari and later, Calabar. Benin and Warri were probably only places to receive greater attention from the early European visitors to the Nigerian coast. During the Atlantic slave trade of the following centuries, the port of Bonny became an important centre in this part of Africa.

Because of its early prominence, Bonny has attracted the attention of Nigerian historians. Dr K. O. Dike first drew attention to Bonny in his study of British economic and political activity, in Trade and Politics in the Niger Delta (1830-1885), published in 1956. This study shows that Bonny became important too in the palm-oil trade that succeeded the slave trade, although its position of leadership in the Eastern Delta was taken over by offshoot settlement of Opobo, after 1870. In The Trading States of the Oil Rivers (1963), G. I. Jones devoted a chapter to the history of Bonny, but his other chapters on the internal working of the House System were devoted to the system as it operated among the Kalabari.

.... Bonny (or Grand Bonny, in the records) was a capital city of an ancient kingdom ... ${ }^{I}$

Consequently, due to the strategic position of Grand Bonny Island, virtually all the Kingdom's chieftaincy houses (known as country chieftaincy houses) have their compounds, known as their main seat of governance, in the Island city. ${ }^{2}$

Ancient Bonny Kingdom (Ancient Ibani Nation: Ibanise) has been in existence as a primordial sovereign entity of the Ancient Niger Delta region. The Kingdom was the economic and political centre of the Ancient Niger Delta region and a significant symbol of African civilisation, before the creation of Opobo Kingdom out of it in 1870 and the eventual evolution of modern Nigeria in $1914 .{ }^{3}$ The Kingdom was one of the Ancient Trading States (also called 'City-States') of the Niger Delta region. The Ancient Kingdom was one of the Ancient Ijaw Trading States of the Niger Delta region. Other Ancient Ijaw Trading States are Opobo Kingdom, which emerged in 1870 from Grand Bonny Kingdom), Kalabari (New Calabar), Okrika and Nembe (Brass). These Ancient Ijaw Trading States, along with the Efik (Old Calabar) and Itsekiri (Warri) Trading States are known as Ancient Niger Delta Trading States.

The social system (characteristic organisational pattern) of these Trading States was and still remains similar to that of Ancient Greek City-States. ${ }^{4}$ These Ancient Niger Delta Kingdoms, City and Trading States existed along with their immediate bigger neighbour, within the context and framework of the Southern Minority ethnic nationalities (contemporary South-South Zone) of Nigeria, namely Ancient Benin/Edo Kingdom. ${ }^{5}$ These Ancient Trading States and their neighbouring primordial ethnic nationalities, tribes and communities of present-day southsouth geopolitical zone of Nigeria make up the true Niger Delta region, known as the ethnographic, geographic and historical Niger Delta region, which is distinct from the politically motivated Niger Delta region created by the Niger Delta Development Commission (NDDC) Act. ${ }^{6}$

Ancient Grand Bonny Kingdom is in modern Nigeria presently delineated by the Bonny Local Government Area (OLGA). OLGA was created in 1991, by the administration of Military President General Ibrahim Babangida. ${ }^{7}$

\footnotetext{
${ }^{1}$ E. J. Alagoa and A. Fombo (n1), vii-viii; Bonny Joint Industry Committee (JIC) led by NLNG, 'Bonny Kingdom Masterplan | Bonny Island, Nigeria | 2014'< $<$ https://www.nleworks.com/case/bonny-kingdom-masterplan/> Accessed 27 March, 2020.

${ }^{2}$ E. J. Alagoa and A. Fombo (n1), viii; E. T. Bristol-Alagbariya (2010 [7]), 105-106.

${ }^{3}$ K. O. Dike, Trade and Politics in the Niger Delta 1830-1885: An Introduction to the Economic and Political History of Nigeria (Greenwood Press 1981), 31; E. T. Bristol-Alagbariya, (n7), 109; Federal Republic of Nigeria, Nigeria at 50: A Compendium: The Official and Authoritative Book about Nigeria (Published on the Golden Jubilee Independence Anniversary www.1stoctober.com Publishing 2010), 33.

${ }^{4}$ K. O. Dike (n9), 30-31; E. T. Bristol-Alagbariya (2010 [7]), 106; National Geographic Society, 'Greek City-States' $<$ https://www.nationalgeographic.org/encyclopedia/greek-city-states/> Accessed 27 March, 2020.

${ }^{5}$ Federal Republic of Nigeria (n9), 26.

${ }^{6}$ Sections 2 (1) (b) and 4 of the Niger-Delta Development Commission (Establishment) Act, Act No 6 LFN 2000, Cap N86 LFN 2004; Niger Delta Development Commission (Establishment) Amendment Act, 2017; Niger Delta Development Commission (NDDC), Niger Delta Regional Development Master Plan (NDDC 2006), 49-50, 53-55, 60-67.

${ }^{7}$ E. T. Bristol-Alagbariya (2010 [7]), 105-106.
} 
The strategically located, traditionally centralised and petroleum resources-rich Bonny Kingdom and OLGA, are also inhabited by many immigrant job seekers and the workforce of several multinational oil and gas companies (MNOCs), such as Shell Nigeria (the Shell Petroleum Development Company of Nigeria Limited [SPDC]), Nigeria LNG Limited (NLNG), Mobil Producing Nigeria Unlimited (MPNU, a subsidiary of ExxonMobil), Chevron Nigeria (Chevron Nigeria Ltd. [CNL), among other allied business organisations. ${ }^{1}$

Consequently, Bonny Kingdom or OLGA is one of the most industrialised areas of Nigeria ${ }^{2}$ and this has been so from time immemorial, as it is one of Nigeria's foremost strategic areas of external relations, especially external trade ${ }^{3}$ due to its numerous residents, namely its working class and job seeking residents, as well as indigenes. As such, the population of the Kingdom is about 600,000 people. ${ }^{4}$ In the earliest times, Bonny Kingdom had such trade and exchange items as indigenous salt, ivory, Guinea pepper. After the $15^{\text {th }}$ Century era of the early Western European explorers, visitors and traders, the trade and exchange items of the Kingdom included slaves (from the $16^{\text {th }}$ Century to the $19^{\text {th }}$ Century [1807]) $)^{5}$ and later on (after slave trade had been outlawed in the $19^{\text {th }}$ Century onwards) legitimate trade in oil-palm produce was the basic item of trade and commerce of Bonny Kingdom. ${ }^{6}$ Thereafter, from the late 1950s, the Atlantic coast of Bonny and OLGA became Nigeria's strategic location for exporting petroleum (crude oil and natural gas) resources, for the country's overseas consumer-nations and consumer-public around the globe. ${ }^{7}$

On the whole, the God-given strategic location of Bonny Kingdom has made the Kingdom to occupy a significant position and place of pride from earliest times to present-day. This may be considered in the following manner: (i) from the primordial era (when the Kingdom was founded [before about AD 1,000] ${ }^{8}$ to the $15^{\text {th }}$ Century AD [when the early Western European explorers and merchants arrived the Niger Delta region; (ii) thereafter, from the period of British imperialism (premised on the signing of negative sovereignty treaties ${ }^{9}$ with the Trading States of the Niger Delta region in 1884 - 1914, when formal British colonial rule commenced in pre-colonial Nigeria, through a series of political amalgamation); and (iii) later-on, during the period of formal British colonial enterprise in Nigeria (from 1914 up to 1960) up to the ongoing era of economic globalisation in the Niger Delta region. It may be highlighted that in the course of the Scramble and Partition of Africa among the Western European imperialists, after the Berlin West African Conference of 1884/1885, the British declared a Colonial Protectorate of over Ancient Grand Bonny Kingdom and other Niger Delta Trading States and their coastal, mainland and hinterland neighbouring areas that formed the British districts of the Niger Delta, namely the British Colonial Protectorate of Niger Districts in 1885, which marked the end of the Primordial Sovereign Statehood of the Ancient Kingdom as well as the Natural Sovereign status of other primordial ethnic nationalities of the British Colonial Protectorate of Niger Districts. The British Colonial Protectorate of Niger Districts was renamed the Oil Rivers Protectorate in 1889, and thereafter the Niger Coast Protectorate in 1893, consequent upon which the entire Niger Delta region eventually became a part and parcel of the Colony and Protectorate of Southern Nigeria in 1890 and ultimately the Colony and Protectorate of Nigeria (modern Nigeria) in $1914 .{ }^{10}$ For instance, due to its strategic location, Ancient

${ }^{1} \mathrm{Ibid}, 117-118$ and $112-113$.

${ }^{2}$ Bonny Joint Industry Committee (JIC) led by NLNG (n6).

${ }^{3}$ Encyclopaedia Britannica, 'Bonny: Nigeria' $<$ https://www.britannica.com/place/Bonny $>$ Accessed 27 March, 2020.

${ }^{4} C / f$ City Population, 'Bonny Local Government Area in Nigeria: Population' $<$ http://www.citypopulation.info/php/nigeriaadmin.php?adm2id=NGA033007> Accessed 27 March, 2020.

${ }^{5}$ Somerset $v$ Stewart [1772] 98 ER 499; S. M. Wise, Though the Heavens May Fall: The Landmark Trial That Led to the End of Human Slavery (Da Capo Press 2006); N. S. Poser, Lord Mansfield: Justice in the Age of Reason (McGill-Queen's University Press 2013); Federal Republic of Nigeria (n9), 27-28.

${ }^{6}$ N. Briggs et al (eds), The Economic Development of Rivers State: In Commemoration of Port Harcourt Celebration 2013 (Onyoma Research Publications 2013), 67-85.

${ }^{7}$ E. T. Bristol-Alagbariya (2010 [n7]), 24, 26-28, 31 and43

${ }^{8}$ E. J. Alagoa and A. Fombo (n1), 5; Letter of Duawaris to His Majesty, King Edward Asimini William Dappa Pepple III, CON, JP, captioned inter alia 'Re: Ongoing Out-Of-Court Settlement Discussions of Duawaris Suit No: FHC/PH/CS/04/2017 (pending at the Federal High Court, Port Harcourt) Concerning the Proposed Bonny Kingdom Development Foundation (BKDF)' dated 9 January, 2019, signed by Aseme-Warisenibo Elliott D. Dublin-Green (Registered Trustee/Secretary) and Aseme-Warisenibo Reginald Ayi Cross Brown (Registered Trustee/Coordinator), 6.

${ }^{9}$ G. I. Jones (n2), 243-245, captioned 'Treaty between Great Britain and New Calabar, 1884', signed on behalf of Great Britain by Edward Hyde Hewett.

${ }^{10}$ E. J. Alagoa and A. A. Derefaka (eds), The Land and People of Rivers State: Eastern Niger Delta (Onyoma Research Publications 2002), 324-326; E. T. Bristol-Alagbariya (2010 [7]), 130; J. C. Anene, Southern Nigeria in Transition 1885-1906: Theory and Practice in a Colonial Protectorate (Cambridge University Press 2009); M. Crowder, The Story of Nigeria (Faber and Faber 1978), 188-206; S. Forster et al (eds), Bismarck, Europe and Africa: The Berlin Africa Conference, 1884-85, and the Onset of Partition (Oxford University Press 1989); T. Pakenham, The Scramble for Africa (Abacus 1992/2003); Charles River Editors, The Scramble for Africa: The History and Legacy of the Colonization of Africa by European Nations during the New Imperialism Era (Charles River Editors 2017); F. J. Lugard, 'Lugard in Nigeria: Report on the Amalgamation of Northern 
Grand Bonny Kingdom served as a middleman during the periods of the Atlantic trade in slaves and Atlantic trade in oil palm produce in the Niger Delta region from about the $16^{\text {th }}$ Century to the $19^{\text {th }}$ Century. ${ }^{1}$ Thereafter, in modern Nigeria, Bonny was the first seat of the government of River State, when the state was created by General Yakubu Gowon in May 1967, during the Nigerian Civil War. ${ }^{2}$ Furthermore, in modern Nigeria (from about 1958, following the commercial discovery and production of crude oil in the Niger Delta region), in the course of the ongoing over six decades of petroleum resources development operations in the oil-rich Delta region, ${ }^{3}$ Bonny Kingdom has remained a key strategic export route of these resources to Nigeria's overseas consumer-countries and consumer-populace around the world. Bonny Island is thus housing Nigeria's first crude oil (later-on crude oil and gas) export terminal as well as the country's first Liquefied Natural Gas (LNG) export terminal.

In contemporary Nigeria, Bonny Kingdom is hosting several MNOCs, indigenous oil and gas companies and allied businesses, which mainly operate in Bonny Island and Finima Community of the Kingdom, which is situated along Bonny Island Community. ${ }^{4}$

\subsection{Grand Bonny Kingdom: Its Origin, Cradle of its Civilisation and Common Heritage}

Ancient Bonny Kingdom was founded on virgin lands and territories by some blood descendants of Ebeni, an Ijaw ancestor of the Ebenitoru (i.e., Ebeni River) area of the freshwater central Niger Delta in the Central Niger Delta, which is the heartland of the Ijaws, Nigeria's fourth largest ethnic group. ${ }^{5}$ The leading men of the Founding Group were Opuamakuba, Alagbariye (Kala-beni, also known as Alagbariya, Alaigbariya, Alagbaria, Alagbarie, Alagbariagha and Alagbarigha), and Asimini, as well as the blood relatives of the trio, namely Ndoli-Okpara and the blood descendants of Kongo. Ebeni is the progenitor of the Founding Ancestors of the Kingdom, consequent upon which the Kingdom (Ibanise) was named after Ebeni. Thus, Ibanise means 'the nation of Ebeni' (Ancient Ibani nation). ${ }^{6}$

The forenamed blood descendants of Ebeni migrated in two streams to found Ancient Bonny Kingdom on virgin lands and territories. The first group was the Priest-King Alagbariya group, which was led by three Patriarchs, namely Opuamakuba, Alagbariya (alias Kala-Beni ['Junior Ebeni']) and Asimini, ${ }^{7}$ as well as the cousin and thus consanguineal kith and kin of the trio, Ndoli-Okpara. The Priest-King Alagbariya Founding Group migrated from their ancestral homeland, Kolokuma, in present-day Kolokuma-Opokuma Local Government Area (LGA) of Bayelsa State. The other group, namely the blood descendants of Kongo, sojourned to the Eastern Delta location of the Kingdom, and established Ikpakpayo, which is popularly known as Finima (present-day Old Finima, which is hosting the plant site and residential area of Nigeria LNG Limited [NLNG]) along Bonny Island. Both Founding Groups of the Kingdom were entirely made up of blood descendants of their progenitor (Ebeni) and members of the Isedani Lineage of Okoloba in Kolokuma. ${ }^{8}$ So, the founders of Ancient Grand Bonny Kingdom migrated from Kolokuma, in the freshwater central Niger Delta into the Atlantic coast of the saltwater eastern Niger Delta, at a place known as Rio Real, where the Ancient Kingdom is located. ${ }^{9}$

In the course of their migration from central Niger Delta, the Priest-King Alagbariya group arrived at Ndoki, where Ndoli-Okpara, the Crown Prince of Ndoki (at the time) joined them. He (Ndoli-Okpara) joined Alagbariya and his two brothers to lead the immigrants further into the eastern Niger Delta, where they founded Orupiri. It was at Orupiri (also called Old Bonny Community/Town) that the government (traditional administration) of the Kingdom, led by its successive Monarchs and other aspects of its civilisation commenced. Orupiri Community

and Southern Nigeria and Administration, 1912-1919' (Unpublished Reports of Library of African Study: Routledge 2004).

${ }^{1}$ K. E. Orji (n5), 36-45.

${ }^{2}$ E. J. Alagoa and A. Fombo (n1), vii-viii and 3.

${ }^{3}$ J. C. Ebegbulem et al, 'Oil Exploration and Poverty in the Niger Delta Region of Nigeria: A Critical Analysis' [2013] 4 (3) International Journal of Business and Social Science, 280.

${ }^{4}$ E. T. Bristol-Alagbariya (2010 [n7]), 105-110.

5 Worldatlas, 'Society: Largest Ethnic Groups In Nigeria' < https://www.worldatlas.com/articles/largest-ethnic-groups-innigeria.html> Accessed 27 March, 2020.

${ }^{6}$ Sections 1 and 3, Constitution of Duawaris (Founding \& Aboriginal Royal Houses) of Grand Bonny Kingdom, captioned 'Brief Description and History of Duawaris (Founding \& Aboriginal Royal Houses) of Grand Bonny Kingdom'; 'Aims and Objectives'; Article 3, The Constitution of Association of Duawaris - Founding \& Aboriginal Royal Houses - of Grand Bonny Kingdom, Corporate Affairs Commission (CAC) of Nigeria, with the CAC Registration No. CAC/IT/No 100619, captioned 'Aims and Objectives'.

7 B. Benatari of IPA, UK (Ijaw National Alliance of the Americas), 'Ijaw History', 3, <https://www.ijawnaa.org/ijaw/home.htm> Accessed 27 March, 2020.

${ }^{8}$ Constitution of the Buoye Omuso (Brown) House of Finima, 2016, i; K. E. Orji, 'The Place of Bonny in Niger Delta History' [2011] 5 (5) (22) African Research Review, 37.

${ }^{9}$ E. J. Alagoa and A. Fombo (n1), 3-4; K. E. Orji (n5), 42. 
may thus be considered significant in the context of the history of Ancient Grand Bonny Kingdom, as a primordial sovereign entity of Ancient Niger Delta and an important feature in the early African civilisation. The Kingdom was founded before or about AD 1,000, long before the arrival of the early European explorers and merchants in the Niger Delta region in the late $15^{\text {th }}$ Century. ${ }^{1}$

At Orupiri, while the immigrants were still in search of a more suitable place of habitation, their young, brave and vibrant Patriarch, Alagbariya, on a hunting expedition, discovered a beautiful virgin island dominated by curlews, 'okolo'.2 Alagbariya named this island, 'Okoloama', which means 'the land of curlews (curlew birds)' or 'curlew town'. Alagbariya reported his discovery of Okoloama to his brothers and the entire people at Orupiri. The leaders and all others accompanied Alagbariya to Okoloama and were satisfied over his great achievement. They then named the Kingdom Okoloama and decided to inhabit it (as their capital city), where Alagbariya was installed Amakoromabo, which means 'Founder of Okoloama': Okoloamakoromabo. ${ }^{3}$ Ibani traditions of origin as well as written records made pursuant to these traditions of origin maintain and sustain the fact that Alagbariya was the leader of the founding team, as well as the discoverer, founder and first indigene of Grand Bonny, ${ }^{4}$ Bonny Local Government Area of Rivers State, Nigeria.

While inhabiting the beautiful Grand Bonny Island City and its environs, the Alagbariya group met their consanguineal kith and kin, namely members of the Kongo Lineage, who had established Ikpakpayo ${ }^{5}$ (popularly known as Finima [present-day Old Finima, which is now the plant site and residential are of Nigeria LNG Limited [NLNG], along Bonny Island). Eventually, the Alagbariya group and members of the Kongo Lineage (being blood descendants of their common ancestor, Ebeni), reunited and became the extended Founding Group of Grand Bonny Kingdom. The major blood descendant-houses of Ebeni are known in the Kingdom as Duawaris. ${ }^{6}$ They are registered by the Corporate Affairs Commission (CAC) of Nigeria, as 'Association of Duawaris - Founding and Aboriginal Royal Houses - of Ancient Grand Bonny Kingdom, with CAC Registration Number CAC/IT/No. 100619. ${ }^{7}$

As Ancient Landmarks, the Patriarchs, Founding Group and entire Founding Generation of Ancient Grand Bonny Kingdom, did not only establish the Kingdom on virgin lands and territories, they also constituted the Kingdom's bedrock vis-à-vis the cradle of the civilisation, commonwealth and entire heritage, which include the institution of traditional rulership, based on the lineage/family/house system, which Kingship (the Monarchy: Amanyanaboship) is at the apex. ${ }^{8}$ The Kingdom's Founding and Aboriginal Group, led by its first four Monarchs, namely NdoliOkpara, Opuamakuba, Alagbariye and Asimini, established its civilisation and entire heritage, which successive

${ }^{1}$ E. J. Alagoa and A. Fombo (n1), vii and 5; The Bonny Chamber of Commerce Industry Mines and Agriculture (BOCCIMA), 'Bonny Kingdom'<https://www.bonnychamber.com/bonny-kingdom/> Accessed 27 March, 2020.

${ }^{2}$ E. J. Alagoa and A. Fombo (n1), 4.

${ }^{3} \mathrm{Ibid}, 7$.

${ }^{4}$ Ibid; K. I. Abbey, A Spot Light on Grand Bonny (K. I. Abbey, 1991), 1; M. A. G. Leonard, The Lower Niger and Its Tribes (Frank Cass \& Co. 1968) 23-24 and 47; K. O. Dike (n9), 24 and 196; E. J. Alagoa et al (eds), The Izon of the Niger Delta (Onyoma Research Publications 2009), 262-263; G. Finapiri, Forgotten Heroes of Grand Bonny (CSS Press 2001) v, 7-9; Bonny Kingdom Historical Society (n4), 20 and 50; Bonny Chiefs' Council, 'Farewell Ceremonies for His Royal Majesty, Captain Opuada Secondus Pepple, King Perekule II, Amanyanabo of Bonny [1996] Bonny Chiefs' Council/Amanyanabo-inCouncil of Bonny Kingdom, 4; Programme of the $20^{\text {th }}$ Coronation Anniversary of His Majesty, Dr Edward Asimini William Dappa Pepple, III, CON, JP, Perekule XI, Natural Ruler and Amanyanabo of Grand Bonny Kingdom, 9; E. J. Alagoa, A History of the Niger Delta (Onyoma Research Publications 2005), 151-152; O. Y. Buowari, The People and Culture of Grand Bonny Kingdom: The Ibani Cultural Heritage (Masterpiece Resources 2014), 7-8 and 189; C. T. C. Ennals (Assistant District Officer), Government of the Federal Republic of Nigeria, Intelligence Report on the Ndoki Clan of Aba Division [Marked File No. EP 10298], paragraph 24, 9; Federal Ministry of Education, Government of the Federal Republic of Nigeria, 'Synopsis of the Reigns of the Monarchs of the Kingdom of Grand Bonny (AD 1200-1878)' [National Archives Marked File No. CALPROF 5/3]; B. A. Obuoforibo, Topics in Bonny Church History (CSS Press 2001), 259; G. I. Jones (n2), 110, 128 and 198 ; E. T. Bristol-Alagbariya (2010 [7]), xxxiii, 106, 108, 113-115, 124 and 137; E. T. Bristol-Alagbariya, Governance Towards Sustainable Development in Nigeria: The Role of Strategic Assessment of Decisions \& Actions (CEPMLP/DUP 2013), 101103.

${ }^{5}$ Constitution of the Buoye Omuso (Brown) House of Finima, 2016, i-iii; Section 1, Constitution of the 'Duawaris' (Founding \& Aboriginal royal houses) of Grand Bonny Kingdom, captioned 'Brief Description and History of the 'Duawaris' (Founding \& Aboriginal royal houses) of Grand Bonny Kingdom'.

${ }^{6}$ K. I. Abbey (n36), 16-17; G. I. Jones (n2), 56, 61-62, 128, 161, 172, 174, 176 and 202; Bonny Kingdom Historical Society (n4), 135-174; O. Y. Buowari (n36), 10, 18 and 19; M. A. G. Leonard (n36), 23-24 and 47.

${ }^{7}$ B. Mahmud, Corporate Affairs Commission Federal Republic of Nigeria Certificate of Incorporation of the Incorporated Trustees of Association of Duawaris - Founding \& Aboriginal Royal Houses - of Grand Bonny Kingdom, dated 13 September, 2017.

${ }^{8}$ E. T. Bristol-Alagbariya (2010 [n7]), 110-126 and 134. 
generations of the people and houses of the Kingdom have been enjoying as common heritage. ${ }^{1}$

\subsection{The House System, Houses and Successive Monarchs of Grand Bonny Kingdom}

It may, in the context of this study, be appropriate to meaningfully and sequentially discuss the house system, houses and successive Monarchs of Grand Bonny Kingdom.

\subsection{The House System and Houses of Grand Bonny Kingdom}

It is germane to discuss traditional rulership in relation to successive Monarchs of Grand Bonny Kingdom in the context of the house system and houses of the Kingdom, as these three issues or subject-matters are related.

The term 'house' ('ward', 'family', or 'lineage') refers to a traditional administrative unit of Ancient Grand Bonny Kingdom and other Ancient Trading States of the Niger Delta. ${ }^{2}$ The house system is extended family unit as well as the basic socio-cultural, political, economic and any other form of conceivable institutionalised administrative unit of the Ancient Niger Delta Trading States, particularly the Eastern Delta City-States of Bonny (and thus by extension Opobo, which evolved from Grand Bonny Kingdom after the 1869 Bonny Civil War, on January 1, 1870), ${ }^{3}$ Elem Kalabari (New Calabar), Okrika and Nembe (Brass). The house system is the core social system and pivot of life and society of these Ancient Niger Delta Trading States. ${ }^{4}$ The system evolved from the Ijaw Lineage system, which the Founding Ancestors of these states derived and inherited from their ancestral Ijaw homeland. ${ }^{5}$ Consequently, the house system has been in existence from the beginning of Ancient Grand Bonny Kingdom. ${ }^{6}$

Considering how the house system has been in existence from time immemorial in Bonny Kingdom, G. I. Jones states as follows:

According to Bonny tradition, the community consisted originally of four wards, derived respectively from Alagbaria, Opu Amakuba, Okpara Ndoli, and Asimini. ${ }^{7}$

These four wards were the founding, aboriginal and inalienable royal wards, lineages or houses, which increased to become five after Alagbariya founded Grand Bonny (Okoloama), when the Alagbariya founding group met and reunited with the blood descendants of their kinsman, Kongo, who had founded Ikpakpayo ('Old Finima'). ${ }^{8}$ On this note, while examining the pedigree of Ibani royal family, M. A. G. Leonard states as follows:

Leaving this for future comment, an examination of the pedigree of the Ibani royal family (vide p. 47 [captioned 'Kings of Bonny'] is tolerably strong evidence in favour of the assertion that 'Alagbariya' was its founder....' K. I. Abbey describes the Ancient Grand Bonny Kingdom's royal houses (Duawaris) in the following words: Duawari Houses ... The founders of these houses are direct descendants of the founders of Bonny. They constitute the royal houses of Bonny. ${ }^{10}$

\footnotetext{
${ }^{1}$ E. D. Dublin-Green and R. A. Cross Brown (Duawaris' ('Association of the Founding and Aboriginal royal houses of Grand Bonny Kingdom'), 'Attention: Kelvin Ebiri, The Editor, Guardian Newspapers of Nigeria (Guardian Nigeria): Disbursement of Shell's N2.45bn Stirs Crisis in Bonny: A Call on Government to Investigate and Enforce Transparency and Accountability of Bonny Kingdom's Public Funds and Enthrone Overall Truth, Equity, Fair-Play and Social Justice in the Affairs of the Kingdom at its Apex Level of Traditional Governance (as Presently Constituted)', dated 19 August, 2019, 3; The Guardian Newspapers, 'Disbursement of Shell's N2.45bn stirs crisis in Bonny' $<$ https://guardian.ng/news/disbursement-of-shells-n245bn-stirs-crisis-in-bonny/> Accessed 27 March, 2020; Cloudpedia, 'Bonny Island' $<\underline{\text { https://cloudpedia.org/bonny-island }>}$ Accessed 27 March, 2020.

${ }^{2}$ E. T. Bristol-Alagbariya (2010 [n7]), 107-110 and 134.

${ }^{3}$ T. Oko-Jaja, 'Opobo Kingdom: Founded January 1870 or December 1870? Part One...' (10 July, 2015) <https://frfr.facebook.com/OpubowatchNewspaper/posts/opobo-kingdom-founded-january-1870-or-december-1870-part-one-bytuonimi-oko-jaja/707376992702202/ Accessed 27 March, 2020.

${ }^{4}$ Encyclopaedia Britannica, 'Itsekiri PEOPLE', <https://www.britannica.com/topic/Itsekiri> Accessed 27 March, 2020; Pulse, 'Itsekiri People: Kingdom History and culture of the Iwere' <https://www.pulse.ng/lifestyle/food-travel/itsekiri-peoplekingdom-history-and-culture-of-the-iwere/2bwtylt> Accessed 27 March, 2020; O. Ikime, Niger Delta Rivalry: Itsekiri Urhobo Relations and the European Presence, 1884-1936 (Longman 1970).

${ }^{5}$ E. J. Alagoa and A. Fombo (n1), 45, 60-67.

${ }^{6} \mathrm{Ibid} ; \mathrm{E}$. T. Bristol-Alagbariya (2010 [n7]), 107-108.

${ }^{7}$ G. I. Jones (n2), 198.

${ }^{8}$ E. T. Bristol-Alagbariya (2010 [n7]), 107-108; Constitution of the Buoye Omuso (Brown) House of Finima, 2016, i-iii, captioned preface, entitled 'Brief History of Buoye Omuso (Brown) House of Finima ...'; N.A.I. Waribere, History of Finima, Bonny \& Her Chieftaincy Houses (Divine Printers \& Publishers Nig. 2008); Chief Samuel O. Tobin \& 2 Ors (For Themselves and For and On Behalf of the Members of Tobin House) $v$ Chief Israel I. Brown \& 3 Ors (For Themselves and For and On Behalf of the Members of Buoye Omuso Brown House (Suit No. PHC/174/72 [2010] 9 Rivers State Law Report, 92-102.

${ }^{9}$ M. A. G. Leonard (n36), 23-24 and 47; G. I. Jones (n2), 56, 61-62, 161, 172, 174, 176 and 202 as well as the table captioned 'Table 3: Structure and Political Alignments of Bonny Houses during the $19^{\text {th }}$ Century'; E. J. Alagoa and A. Fombo (n1), 7 and 89.

${ }^{10}$ K. I. Abbey (n36), 16-17; G. I. Jones (n2), 56, 61-62, 128, 161, 172, 174, 176 and 202; M. A. G. Leonard (n36), 23-24 and
} 47. 
In the course of continuities and dynamic inevitable changes that took place in the post-settlement era of the Founding Generation of Bonny Kingdom, the wards, lineages or houses further increased to become fourteen. Consequently, the Kingdom became popularly known as Okoloama Ingiekiri Fajie, meaning the 'fourteen wards, lineages or houses of Bonny Kingdom'.

Traditional public sector governance and its associated institutionalised all-embracing house systemic form of public administration of aboriginal royal pedigree, based on natural law, both natural right and human right leading to leadership and succession, began with the Founding Generation of Ancient Grand Bonny Kingdom. The nature of the relationship between natural law, natural rights and human rights is such that human rights were derived from and out of the wider concept of natural rights, which are also founded on natural law. Put differently, natural law gave rise to natural rights, which in turn generated human rights. ${ }^{2}$

In primordial Grand Bonny Kingdom, a classical example of natural right of succession to leadership that prevailed, was the ascension of Princess (Aseme-Orubo) Ediminiba Kambasa, who was on instruction of her father, King Edimini (son of Premier King Asimini), to be married to Prince Opoli of Azuogu of the then Ndoki country. However, Princess Ediminiba Kambasa eventually abandoned Prince Opoli, whom she was betrothed to, left Azuogu and returned to Bonny Kingdom. In the process, on the basis of natural law and its inherent natural right of succession to apex leadership position, she succeeded her father, by becoming the Monarch of Bonny Kingdom. ${ }^{3}$

The foregoing is the precise background nature of public sector governance within the rubrics of the house system, organised by the Founding Ancestors of homogenous Ancient Grand Bonny Kingdom and the consanguineal descendants of these Ancestors, before the Bonny Civil War of 1869, during which Opobo Kingdom evolved from the Kingdom and became an independent Ibani Kingdom in 1870, while retaining the house system of governance and its all-embracing institutionalised administration system of its ancestral Ibani homeland (Ancient Grand Bonny Kingdom $)^{4}$

Apart from those that are in Opobo Kingdom, the Founding and Aboriginal royal houses of Ancient Grand Bonny Kingdom which survived inevitable challenges and changes of the post-settlement era of the Kingdom are five in number. This number is beside the Perekule royal house (the King Fubara Manilla-Pepple section of the Perekule royal house, comprised of the Lineages of King George Oruigbi Pepple and his brother, Prince Henry DappayeOnu Pepple), which is considered to have devised the strategy of not publicly identifying itself with the five. The five Duawaris, considered as regular or steady Duawaris, are the houses of senior cousins and uncles of King Perekule. They are Bristol-Alagbarigha royal house (Founder of Grand Bonny: Okoloamakoromabo), King Halliday-Awusa royal house (Bequeather of Kingship on King Perekule), Dublin-Green house (Lala, Ebie, Aboriginal Prince Asimini-Oruakpa lineage), Prince Oruasawo Tolofari royal house (Aboriginal Prince KumaluyaNdende Omuigbem Lineage), and Aboriginal Prince Kongo Lineage: Buoye-Omuso (Brown) major house. Each of the Duawaris (founding and aboriginal royal houses) of Ancient Grand Bonny Kingdom is an Aseme-wari, meaning 'house (family) of aboriginal royal status'.

The term Aseme in Ibani is a time immemorial appellation, status, title and indicator of 'royal pedigree', which

${ }^{1}$ E. T. Bristol-Alagbariya (2010 [n7]), 109.

${ }^{2}$ L. Strauss, Natural Right and History (Charles R. Walgreen Foundation Lectures) (University of Chicago Press 1965); Y. Olomojobi, Human Rights and Civil Liberties in Nigeria: Discussions, Analyses, and Explanations (Princeton \& Associates Publishing Co. 2018), 2; J. Finnis, Natural Law \& Natural Rights (Oxford University Press 2011); C. F. Alford, Narrative, Nature, and the Natural Law: From Aquinas to International Human Rights (Palgrave Macmillan 2010).

${ }^{3}$ I. Sagay, Nigerian Law of Succession: Principles, Cases, Statues and Commentaries (Malthouse Press 2006); R. Kerridge, Parry and Kerridge: The Law of Succession (Sweet \& Maxwell 2016); J. A. Borkowski, Textbook on Succession (Oxford University 2005); D. Ashdown, The Royal Line of Succession: The British Monarchy from Egbert AD 802 to Queen Elizabeth II (Pitkin Publishing 1999); A. Weir, Britain's Royal Families: The Complete Genealogy (Vintage 2008); R. J. Berry, Inheritance and Natural History (William Collins 2013); J. Finnis (n52); Articles 2 and 3, Universal Declaration of Human Rights (UDHR), 1948; Articles 2 and 18 (1) and (2) of the African Charter on Human and Peoples' Rights (Ratification and Enforcement) Act, No.3 1983, Cap A9 LFN 2004 (Cap 10 LFN 1990); Section 14 (1) and 14 (2), 1999 Constitution of the Federal Republic of Nigeria (CFRN) (as amended); E. J. Alagoa and A. Fombo (n1); 8-10, 73 and 89; Bonny Kingdom Historical Society (n4), 53-54.

${ }^{4}$ E. T. Bristol-Alagbariya $(2010$ [n7]), 109.

${ }^{5}$ E. J. Alagoa and A. Fombo (n1), 6; Sections 1 and 6, Constitution of the 'Duawaris' (Founding \& Aboriginal Royal Houses) of Grand Bonny Kingdom, respectively captioned 'Brief Description and History of the 'Duawaris' (Founding \& Aboriginal royal houses) of Grand Bonny Kingdom', and 'Ibanise KoromaTaduapu Kubiri'(meaning, 'Council of the Founding Ancestors \& Aboriginal Owners of Ancient Grand Bonny Kingdom)'. 
pinpoints an individual as well as a lineage or house of 'aboriginal royal status' in Ibaniland. The Founding Ancestors of the Kingdom are the 'first Asemes. Hence, the appellation Asemes (plural), connote and denote the Founding Ancestors of Ancient Ibaniland and their houses, as well as the status and title of the blood descendants and blood descendant-houses of the Kingdom. While an Aseme is an aboriginal royal individual, an Aseme-wari ('the house of an Aseme') means an aboriginal royal house or any other blood descendant lineage or house, be it a Major Aseme-wari (royal house) or Minor Aseme-wari (royal house). Hence, whereas Duawaris of Bonny Kingdom are the lineages or houses of the Founding Ancestors and Major houses of their blood descendants as well as the King Fubara Manila Pepple stock of the Perekule royal house, Aseme-waris are the Duawaris and minor houses of the Duawaris that are blood descendant minor houses of the Kingdom. Thus, Aseme-waris mean or refer to more blood descendant houses than Duawaris. Blood descendants of the Founding Ancestors and other members of Minor houses of Duawaris may however be chosen by their Duawaris to represent their Duawaris on Duawaris' affairs or any issue of Duawaris.

An Aseme could be an Asemebo ('person of aristocratic-nobility or aristocratic-birth') or distinctively AsemeOwibo (Aseme-Owutuwo: 'man of aristocratic-nobility or aristocratic-descent') or Aseme-Orubo ('woman of aristocratic-nobility or aristocratic-birth') in the Kingdom. Being naturally royal by virtue of birth right (as per being blood descends of the Founding Ancestors of the Kingdom),_Aseme is a subject-matter of natural law and its accompanying natural right. Accordingly, the subject-matter of Aseme is one of universally acknowledged, agreed and respected human rights, arising from natural law and its accompanying inalienable natural right of individuals created by God Almighty as Founding Ancestors and blood descendants of these Ancestors of Ancient Grand Bonny Kingdom (Ibanise). ${ }^{1}$

The term Aseme became distinctly pronounced from the period the Kingdom became no longer homogenously made up of its ancestral Ijaw aboriginal in population; from the period shortly before or about the $18^{\text {th }}$ Century AD onwards, when foster descendants assimilated into the Kingdom and their houses known as created chieftaincy houses became parts and parcels of the Kingdom. ${ }^{2}$ As such, Aseme obviously became an individual that is 'given birth to from and/or into royal pedigree, otherwise called alayingi furo (meaning 'mother royal status' or 'birth right-oriented royal status'), as against an individual who achieved 'royal' status in the Kingdom; the same applies to Aseme-wari ('house of Aseme'), as a house of aboriginal royal descent and/or status in the Kingdom, arising from the inalienable royal status of Founding Ancestors and Founding and Aboriginal royal houses of the Kingdom. As distinct from the War Canoe (Major Chieftaincy) houses of foster descendants of Bonny Kingdom created from the $18^{\text {th }}$ Century AD (beginning with the creation of the Allison-Nwaoju major house and the making of AllisonNwaoju a Se-Alabo [Country Chief] by King Perekule), a major Aseme-wari is a Duawari, namely an Autochthonous Canoe house (an aboriginal royal house) of any of the Founding Ancestors of the Kingdom or that of any blood descendant of the Founding Ancestors. ${ }^{3}$ Therefore, apart from the Founding Ancestors (who are 'Premier Asemes' of the Kingdom), an Aseme is a noble personality of aristocratic descent (a God-given [divine] natural hereditary status of nobility) among Ibani people. ${ }^{4}$ Among apex traditional rulers of Bonny Kingdom, Aseme-Alapu or Aseme-Se-Alapu are heads of Duawaris and heads of blood descendant minor houses of the Duawaris. ${ }^{5}$ By virtue of natural law and its accompanying natural right to succession, Bonny Kingdom's blood descendant-houses (Aseme-waris) may be categorised into two: major and minor houses, namely Opu Aseme-waris (Duawaris: major and aboriginal royal houses) and Kala-Aseme-waris (minor royal houses). ${ }^{6}$

So far, only those who are Asemes of Duawari extraction have become Monarchs of Ancient Grand Bonny Kingdom, as kingship (the Monarchy) of the Ancient Kingdom is an exclusive reserve of Asemes. The Monarchy has therefore, from time immemorial to the contemporary era of the Kingdom, been steady and sustained among the Asemes of Duawari extraction. ${ }^{7}$

\footnotetext{
${ }^{1}$ Ibid.

${ }^{2}$ E. J. Alagoa and A. Fombo (n1), 46, 54 and 75.

${ }^{3}$ K. I. Abbey (n36), 16-17; M. A. G. Leonard (n36), 23-24; E. J. Alagoa and A. Fombo (n1), 3, 7, 45-46, 49, 50, 53-55, 6067 and 75; O. Y. Buowari (n36), 7-13, 18-19 and 189; G. I. Jones (n2), 56, 61-62, 161, 172, 174, 176 and 202.

${ }^{4}$ E. J. Alagoa and A. Fombo (n1), 6; C/f Sections 1 and 6, Constitution of the Duawaris (Founding \& Aboriginal royal houses) of Grand Bonny Kingdom, respectively captioned 'Brief Description and History of the Duawaris (Founding \& Aboriginal royal houses) of Grand Bonny Kingdom', and 'Ibanise KoromaTaduapu Kubiri' (meaning, 'Council of the Founding Ancestors \& Aboriginal Owners of Ancient Grand Bonny Kingdom)'.

${ }^{5}$ Ibid.

${ }^{6}$ C. F. Alford (n52); L. Strauss (n52); J. Finnis (n52); Y. Olomojobi (n52); I. Sagay (n53); R. Kerridge (n53); J. A. Borkowski (n53); D. Ashdown (n53); A. Weir (n53); R. J. Berry (n53); G. I. Jones (n2), 128; E. J. Alagoa and A. Fombo (n1), 17, which makes reference to 'the big free born chiefs and the priests ...'

${ }^{7}$ E. J. Alagoa and A. Fombo (n1), 6 and 89; Programme of the 20th Coronation Anniversary of His Majesty, Dr Edward Asimini William Dappa Pepple, III, CON, JP, Perekule XI, Natural Ruler and Amanyanabo of Grand Bonny Kingdom, 9; G. I. Jones
} 
Moreover, given that the status of Aseme is the basis, foundational outlay and bedrock of royalty in Ancient Grand Bonny Kingdom and realising this historical fact and aboriginal custom of the Kingdom, while discussing the Kingdom's royal institution in relation to the Anna Pepple House as against the background of the lineages/houses of Alagbariya and Asimini, G. I. Jones unequivocally states as follows:

Even if the Anna Pepple House did achieve this, its head would never be accepted in Bonny as King, as he was not of Pepple or of Asimini or Alagbaria descent. ${ }^{1}$

Also, as already indicated above, with regard to the pedigree of the Bonny (Ibani) royal family and in the context of the Founding Father, Patriarch, Premier High-Priest and Aboriginal Monarch of Ibaniland, Alagbariya, in particular, M. A. G. Leonard clearly states that ... an examination of the pedigree of the Ibani royal family ... is tolerably strong evidence in favour of the assertion that 'Alagbariya' was its founder. ${ }^{2}$

Suffice it to mention further that about the above-stated $18^{\text {th }}$ Century AD was when Perekule became the Monarch in Bonny Kingdom and bestowed chieftaincy status as well as commenced the creation of chieftaincy houses among foster descendants and foster descendant houses of King Perekule. However, the chieftaincy status being bestowed and chieftaincy houses being created are not accorded 'royal' status. Rather, directly or indirectly, the traditional administration of some succeeding Perekule Monarchs have tactfully been endeavouring to dispossess their Duawari blood-brothers and blood-brotherhood houses of their natural royal status, based on which King Perekule and his blood descendants are equally Asemes and thus aboriginally royal as those of the rest of Duawaris. This tactful endeavour, which non-Bonny people and interest groups, seem not to properly understand nor fully appreciate, is being promoted and entrenched in Bonny to the detriment of the rest of the Duawaris and their lots, who have become neglected and marginalised minorities in their God-given aboriginal homeland. ${ }^{3}$

Meanwhile, moving away from the issue of Aseme, it may be pointed out that the rest of the major houses of Ancient Grand Bonny Kingdom that are not Duawaris are nine in number, and they are known as Opuwaris (which are houses of the foster descendants of the Founding and Aboriginal stocks of the Kingdom). These are namely Nwaoju (Allison) house, Fubara Manilla Pepple house (which the blood descendants of the Lineages of King George Oruigbi Pepple and his brother, Prince Henry Dappaye-Onu Pepple, are its original stock), Captain Adango Hart (Akunnayi) house, Jumbo (Sinaminasobo-ofori/Okponkata) house, Banigo (Ibaningo/Eringeresibo) house, Wilson Oju-igbe Pepple (Nkwerre) house, Wilcox (Wirikoma/Egede) house (that originated from ancient Bille), Finecountry (Ibiama) house and the LongJohn (Amonibienye-Ofori) house. The five Duawaris and nine Opuwaris of Grand Bonny Kingdom comprise contemporary Okoloama Ingiekiri Fajie of the Kingdom. In other words, These fourteen major houses of Grand Bonny Kingdom are the present-day Okoloama Ingiekiri Fajie, same as the Opobo Kingdom has its fourteen sections to which the sixty seven houses of the Kingdom belong. The fourteen sections of Opobo Kingdom also described as 'polos' are namely Jaja [Jeki] Polo, Dappa-ye Amakiri Polo, Tolofari Polo, Kala-Omuso Polo, Diepiri Polo, Dappu Polo, Ukonu Polo, Kiepirima Polo, Iruanya Polo, Epelle Polo, Biriye Polo, Owujie Polo, Fubarakuro Polo and Adibie Polo. ${ }^{4}$

(n2), 128

${ }^{1}$ G. I. Jones (n2), 128.

${ }^{2}$ M. A. G. Leonard (n36), 23-24 and 47.

${ }^{3}$ The Constitution of Bonny, which was produced about the 1980s, whereas Bonny Kingdom was founded before or about AD 1, 000. Among other issues, this Constitution is silent on the history of the Kingdom, as well as the history of the component houses and Ibani names of some of the houses of the Kingdom; Letter of Bonny Chiefs Council, with reference No. BCC/EM.INFO.HOUSES/VOL.1/75, dated July 24, 2017, signed by Se-Alabo Arthur L. S. Willie-Pepple (Secretary), which letter purports to compulsorily insert the word 'Chieftaincy' on the letter headed paper and flags of all houses of the Kingdom, and thereby amounting to renaming the houses, even the five steady Duawaris, which consider this letter as being particularly directed at them, contrary to natural law. Given that the term Aseme is a time immemorial indicator of royal pedigree in Ibaniland, to estrange such Ancestors, their blood descendants and the lineages or houses of the same Ancestors and those of their blood descendants, their God-given heritage and in their own Ibaniland, several millennia after the origin and continued existence of land, is arbitrary and thus contrary to natural law and its accompanying natural right and rule of fair-play in society. Holy Bible, Proverbs 22:28; Proverbs 23:10; Deuteronomy 19:14; Job 24:2; Hosea 5: 10; Deuteronomy 27: 17; 1 Corinthians 3:11; John 8: 32 and 35. As demonstrated by the Ibani name, Kampayo-ofori, meaning 'there is nowhere that there is no dispute', mere discriminatory, pure diversionary and thus 'fictional' disputes or misunderstandings between the steady Duawaris and the Perekule royal house (which are being unfairly orchestrated in Bonny Kingdom against the steady Duawaris) do not constitute sufficient reason to dispossess these Duawaris of their God-given birth right status of aboriginal royal pedigree, which is universally protected by law. Article 2, Universal Declaration of Human Rights (UDHR), 1948, Article 2, African Charter on Human and Peoples' Rights (Ratification and Enforcement) Act (Cap A9) LFN 2004; Section 42, 1999 Constitution of the Federal Republic of Nigeria (CFRN) (as amended), captioned 'Right to Freedom from Discrimination'.

${ }^{4}$ A. M. Ogolo, 'Excerpts of Opobo Ibani Traditional Heritages (Part 2) - The Loko Institution in Opobo Kingdom: (An Insight into Tradition) by Senibo Abinye Morgan Ogolo (14 May 2014) $<$ https://web.facebook.com/OpubowatchNewspaper/posts/523688687737701:0?_rdc=1\&_rdr> Accessed 27 March, 2020; G. N. S. Ogolo, Opobo Excerpts (An Insight into An African Kingdom) (Etuk Concepts, 2012), 134, captioned 'Section' 'War 
Apart from the fourteen major houses of Grand Bonny Kingdom, there are twenty minor houses of the Kingdom. These are namely Willie-Pepple house, Jim-Halliday house, Attoni house, Tobin house, Jackmay house, JekeyGreen house, Christie-Wilcox house, Dappa-Wilcox house, Jack Manilla house, Allaputa house, Pollyn house, Ada-Allison house, Jamaica-Allison house, Abbey-Hart house, Abraham-Hart house, Ezekiel-Hart house, DanJumbo house, John-Jumbo house, Stowe/Benstowe house, and the Dick-Obunku (Beresiri) house.

While some of the major houses of Grand Bonny Kingdom were created out of Duawaris, particularly from the foster descendants of the Fubara Manilla Pepple's section of the Perekule royal house, the minor houses were created out of Duawaris and the rest of the major houses of the Kingdom. It may therefore be noted that the Igweyi group of houses were created out of the Bristol-Alagbarigha royal house (Founder of Grand Bonny: Okoloamakoromabo), wherein Igweyi was a member of the King Bereibibo Alagbariya Lineage. The Igweyi group of houses are Ibiama (Finecountry) major house (which was created in favour of Igweyi, a foster son of King Bereibibo Alagbariya), and the Willie-Pepple and Jackmay minor houses. ${ }^{2}$ Accordingly, the Jekey-Green house was created by the Dublin-Green house. ${ }^{3}$

By and large, along with the Perekule Royal house, Grand Bonny Kingdom is presently made up of thirty six houses, whereas Opobo Kingdom that evolved from Grand Bonny Kingdom has sixty seven houses. ${ }^{4}$ As those of other sister Kingdoms, the houses of Grand Bonny Kingdom and Opobo Kingdom mastermind the traditional governance and key aspects of public administration of these two Ibani Kingdoms. However, more than what prevails in some of their sister Kingdoms, the people and houses of these two Ibani Kingdoms rely more on the house systems of governance and their traditional rulers therefrom, especially those of the apex traditional ruling councils of the two kingdoms, than Nigeria's constitutionally guaranteed civil governance in the kingdoms (the Bonny Local Government and Opobo-Nkoro Local Government).

The houses of Grand Bonny Kingdom, Opobo Kingdom and those of other Ancient Niger Delta Trading States are often called chieftaincy houses. These institutionalised traditional governance and public administrative-extended family units, known as houses, are spread within and outside Rivers State of Nigeria, within the Nigerian Delta region, South-South geopolitical zone of the Federal Republic of Nigeria. Some generally refer to these houses in a loose form as chieftaincy houses. In recognition of the sovereign status of Ancient Grand Bonny Kingdom before the political evolution of modern Nigeria from 1914, the chieftaincy houses of the Kingdom are known as country chieftaincy houses (chieftaincy houses of the Ancient Ibani nation).$^{5}$

\subsection{Successive Monarchs of Ancient Grand Bonny Kingdom}

The list of the Monarchs of Ancient Grand Bonny Kingdom is somehow numerous. This list varies with regard to certain names and numbers in the works of several authors. Relying on the list recorded by E. J. Alagoa and A. Fombo and also the programme of the $20^{\text {th }}$ Coronation Anniversary of His Majesty, Dr Edward Asimini William Dappa Pepple, ${ }^{6}$ Bonny Monarchs are so far twenty three in number. They are Ndoli-Okpara, Opuamakuba, Alagbariye (Alagbariya) and Asimini. Others are Edimini, Kambasa, Kumalu, Opu Dappa, Amakiri, Appia, Wari and Awusa (Halliday or Halliday-Awusa). The rest are Perekule, Adum-Fubara, Adum-Opubu (Opubo), Adumtaye-Bereibibo, William Dappa Pepple, Dapuye-Fubara, George Oruigbi Pepple, Secondus George Pepple, Eugene William Dappa Pepple, Captain Opuada Secondus Pepple and Edward Asimini William Dappa Pepple. These Monarchs may thus be considered in three categories.

Canoe Houses'; U. Pepple and T. Oko-Jaja (eds), Contemporary Historical Perspectives on Opobo (Volume One) (Opubowatch Publications 2015), 10.

${ }^{1}$ Section 9, The Constitution of Bonny, captioned 'The Chiefs - Composition Of', ... '(a) ... (b)', 8-9, which Constitution attracted protest from the five steady Duawaris of the Kingdom, captioned 'Protest of Duawaris/royal houses of Bonny on the Draft Constitution for Bonny Kingdom', directed to the Chairman, Ibanise, Bonny, dated 7 February, 1986, copying His Royal Highness, King C. O. S. Pepple, and The Secretary, Bonny Chiefs' Council.

${ }^{2}$ E. J. Alagoa and A. Fombo (n1), 49, 54-59, 60-61, 67, 75 and 89; E. T. Bristol-Alagbariya (2010 [n7), 107.

${ }^{3}$ Judgement of the Supreme Court of Nigeria in SC.206/1986, between Chief Abusi Green v Chief Dr E. T. Earnest Green (SC.206/1986) to the effect that the Jekey-Green house being created by the Dublin-Green house, 'the 'creator' [Dublin-Green house] has the right to impose terms and conditions on his 'creature.'

${ }^{4}$ U. Pepple and T. Oko-Jaja (eds) (n66), 10.

${ }^{5}$ E. T. Bristol-Alagbariya (2010 [n7]), 106-115; E. T. Bristol-Alagbariya (2013 [n36]), 103-104; O. Y. Buowari (n36), 56 and 64; Bonny Kingdom Historical Society (n4), C. T. O. Fombo Hart, Aspects of Bonny in Perspective (Soteria Publishing House 2014), $2-7$.

${ }^{6}$ E. J. Alagoa and A. Fombo (n1), 89, 9, captioned 'King List'; Programme of the $20^{\text {th }}$ Coronation Anniversary of His Majesty, Dr Edward Asimini William Dappa Pepple, III, CON, JP, Perekule XI, Natural Ruler and Amanyanabo of Grand Bonny Kingdom, 9, entitled 'List of Bonny Monarchs'; $c / f$ M. A. G. Leonard (n36), 47, also captioned 'Kings of Bonny'. 


\subsection{The Premier Category of Monarchs, Primordial Sovereign Statehood of the Kingdom and its Harmonious Form of Governance by its Homogenous Founding Kindred Group}

The first category of Monarchs is the Founding Fathers, Patriarchs and co-aboriginal owners of the Kingdom (with the rest of the Founding Generation of the Kingdom), who are the cradle of the institution of public sector governance (now traditional rulership) based on the ward, lineage or house system. As indicted above, these Monarchs were four in number, namely Ndoli-Okpara, Opuamakuba, Alagbariye and Asimini. They are known as Premier as well as Aboriginal Monarchs or Kings. Some, particularly their blood descendants, refer to them as Founding Fathers, Patriarchs as well as Premier and Aboriginal Monarchs. It is from the era of this category of Monarchs that the Ibani title Amanyanabo, meaning 'owner of the land' evolved, as these Monarchs and the rest of the Kingdom's founding group are the aboriginal owners of the entire land and territories of the Kingdom. Amanyanabo is the apex title and office of governance in Ancient Grand Bonny Kingdom. The paraphernalia of the office of Amanyanabo the Crown $(O g u n u)$, staff of office, being an ivory horn or tusk or horn (Odu), Throne (Imine) and a mirror (temedighnye) associated therewith. ${ }^{2}$ The title and office of Amanyanaboship became associated only with apex traditional rulership (rather than apex overall public sector governance) of the Kingdom, when the Kingdom lost her natural sovereign status in modern Nigeria.

At the time of the Founding Fathers, Patriarchs and Premier Monarchs, the traditional rulers of the Kingdom were three principal classes of persons and/or office or title holders, namely (i) the Amanyanabo, (ii) the High-Priest of Ikuba (who, the Amanyanabo chiefly consulted and mostly relied upon for advice and direction and thus was always in dialogue, agreement and understanding with the Amanyanabo), and (iii) the Amadapu, who were the subordinate rulers to the Amanyanabo, as component lineage heads and/or district rulers. ${ }^{3}$ Regents were and also remain known in Ibani as Amadapu. These three principal categories of rulers constituted the Ibanise KoromaTaduapu Kubiri, which means 'Council of the Founders (Ancient Landmarks) of the Kingdom'. ${ }^{4}$

However, the Ibanise Koroma Taduapu Kubiri did not exclusively govern the Kingdom. ${ }^{5}$ The Council governed by engaging the rest of their aboriginal kindred group. In other words, the Council governed along with the rest of their aboriginal kindred group, who constituted a closely-knit homogeneous Ijaw stock. Members of the Council were assisted to reach harmonious decisions, ranging from heads of the wards, lineages or houses (known as Ikpangi Sibidapu), to the rest of their homogeneous aboriginal kindred group. Put otherwise, in the process of ruling the Kingdom, the three aboriginal paramount grades of rulers listened to the 'voices of reason' of their blood relatives (the rest of the homogenous aboriginal kindred group) which make-up the kingdom at the time.

It may be noted that the 'voice of reason' ('rationalism', otherwise put as 'soundness') is a characteristic feature of good public sector governance (GG), and to that extent an inevitable aspect of GG, as well as a key feature towards the advancement and prosperity of society. ${ }^{6}$

Together, all individuals that made up the aboriginal blood-related kindred group of Ancient Grand Bonny Kingdom (Ancient Ibani nation) were known as Asemes. It has already been explained that the Asemes are the Founding Ancestors (Ancient Landmarks) of the Kingdom and their blood descendants. ${ }^{7}$

Given that Aseme is a title of an individual of royal ancestry, Asemes, especially their leaders (namely Monarchs ['Amanyanapu'] and Chiefs [Aseme-Alapu]), wear a royal robe called Ikaki-bite (Cloth of the Tortoise'), which

\footnotetext{
${ }^{1}$ E. J. Alagoa and A. Fombo (n1), 7.

${ }^{2}$ Bonny Kingdom Historical Society (n4), 42; E. J. Alagoa and A. Fombo (n1), 8 and 10.

${ }^{3}$ E. J. Alagoa and A. Fombo (n1), 6.

${ }^{4}$ Section 6, Constitution of the Duawaris (Founding \& Aboriginal royal houses) of Grand Bonny Kingdom, captioned Ibanise KoromaTaduapu Kubiri (meaning, 'Council of the Founding Ancestors \& Aboriginal Owners of Ancient Grand Bonny Kingdom)'; Article 7, The Constitution of Association of Duawaris - Founding \& Aboriginal royal houses - of Grand Bonny Kingdom, Corporate Affairs Commission (CAC) of Nigeria, with the CAC Registration No. CAC/IT/No 100619, captioned 'Governing Body'. The Ibanise KoromaTaduapu ('the Founding Ancestors of the Kingdom' are also the Ibanise YanaTaduapu ('the Aboriginal Owners of the Kingdom').

${ }^{5}$ Ibid.

${ }^{6}$ B. Shapiro, The Right Side of History: How Reason and Moral Purpose Made the West Great (Broadside Books 2019); L. Peikoff (ed), The Voice of Reason: Essays in Objectivist Thought (Penguin Books 1990); D. Lama, The Little Book Of Wisdom (Rider 2000).

${ }^{7}$ Constitution of the Duawaris (Founding \& Aboriginal royal houses) of Grand Bonny Kingdom; The Constitution of Association of Duawaris - Founding \& Aboriginal royal houses - of Grand Bonny Kingdom, CAC Nigeria Registration No. CAC/IT/No 100619 .
} 
was originally 'ngu-ikaki-bite'. 'Ikaki-bite', and in many ramifications Ikaki itself, signifies royalty among Ibani people, particularly a symbol of royal descent of Asemes among the people and non-Ibani people (foreigners). The tortoise (Ikaki) is therefore an integral part of the aboriginal insignia of Ancient Grand Bonny Kingdom, as well as the insignia of some of its royal houses, such as that of Bristol-Alagbarigha Royal House (Founder of Grand Bonny: Okoloamakoromabo). In the same manner, demonstrating their descent from the Founding Ancestors, aspects of the talking drum ${ }^{2}$ name of Ancient Grand Bonny Kingdom (Ancient Ibani nation) is reflected in the insignia of some of the royal houses (Duawaris ['houses of the Asemes; Aseme-waris]) of the Kingdom, such as those of the King Perekule Aseme-wari (royal house) and the Bristol-Alagbarigha Aseme-wari (royal house [Founder of Grand Bonny: Okoloamakoromabo]).

In the earliest time of Ancient Grand Bonny Kingdom, when the kingdom was entirely made up of its homogeneous ancestral Ijaw stock, governance (public sector governance) was precisely a collective affair of the Asemes. In other words, the characteristic form of public sector governance at the time was its characteristic feature of harmonious decision-making and decision-implementation processes between and among the Asemes, which processes were influenced by 'the voice or voices of reason' of the entire people. ${ }^{3}$

Essentially, during the era of the 'Premier Monarchs' of the Kingdom, herein referred to as the era of 'first category of Monarchs', the Kingdom established its ingredients of sovereign statehood, as a primordial Ancient Niger Delta state. These ingredients of sovereign statehood are a permanent population, a defined territory, a government (based on its peculiar domestic system) and the capacity to enter into foreign relations (relations with other sovereign states). ${ }^{4}$

At the time, Ancient Grand Bonny Kingdom entered into foreign relations with some of their neighbouring primordial sovereign states and other naturally independent ethnic nationalities and sovereign entities, which eventually became parts and parcels of modern Nigeria. The Kingdom also entered into external relations with the Western European nations, with which it established contacts in the early times. Thus, while maintaining steady relations with their Aboriginal Ebeni-toru Central Ijaw (Ijo) homeland, particularly, Kolokuma, neighbouring primordial sovereign states that Ancient Grand Bonny Kingdom entered into foreign relations within the Niger Delta include the Elem Kalabari Bonny Kingdom (Old Calabar), New Calabar Trading State (the Efik City-State), Nembe-Brass and Okrika Trading and City-States, and the Ancient Benin Empire, as well as the Niger Delta mainland ethnic nationalities, such as Ndokiland, Opu-Oko and Kala-Oko in Ogoniland, as well as primordial communities of Andoni (Obololand). Outside the Ancient Niger Delta region, which constitutes contemporary South-South zone of Nigeria, Ancient Grand Bonny Kingdom entered into foreign relations with communities of the Igbo hinterland ethnic nationality, Igala of the Middle-belt, and those of primordial Yorubaland, from whom the people of the Kingdom derived such trade items as the Yoruba traditional hand-woven and dyed cotton clothes such as Ikaki-bite (Cloth of the Tortoise') and those known as Ashoke (aso oke) ${ }^{5}$ in exchange for such traditional trading and exchange items of the Kingdom. These include native salt, dried fish and other forms of seafood and primordial fishing gear; besides weaved products, such as basket tray, basket bags, basket traps and basket rafts; pottery and a measure of carved items such as art works. ${ }^{6}$ Along with these products, those of Ancestral Ijawland include such carved products as canoes, paddles and walking sticks, while cast bronze, carved ivory and other artworks were produced by the Edo (Ancient Benin) people. On the other hand, the commodities of trade and exchange of the Delta mainland and Igbo hinterland areas were mainly agricultural products, which included livestock such as fowls, cows, goats and sheep. Other agricultural good were yam, cocoyam, coconut, banana and plantain. The trade and exchange items of the Igala ethnic nationality of Kogi State in the Middle belt, included iron ore technological items. ${ }^{7}$

\footnotetext{
${ }^{1}$ E. J. Alagoa and A. Fombo (n1), 6; M. G. Anderson and P. M. Peek (eds), Ways of the Rivers: Arts and Environment of the Niger Delta (Regents of the University of California 2002), 251-267.

${ }^{2}$ Encyclopaedia Britannica, 'Talking drum' $<$ https://www.britannica.com/art/friction-drum>; Cultures of West Africa, 'The Talking Drum' $<$ https://www.culturesofwestafrica.com/talking-drum/> both Accessed 27 March, 2020.

${ }^{3}$ E. J. Alagoa and A. Fombo (n1), 6; M. G. Anderson and P. M. Peek (eds) (n75), 251-267.

${ }^{4}$ A. James, Sovereign Statehood: Basis of International Society (HarperCollins Publishers 1986).

${ }^{5}$ Ndigo Arts Gallery, 'Yoruba Ashoké (aso oke) Cloth from Nigeria' < https://indigoarts.com/galleries/yoruba-ashok-aso-okecloth-nigeria $>$ Accessed 7 March, 2020; Bellafricana, 'The History of Aso-Oke Textile' $<$ https://bellafricana.com/the-historyof-aso-oke-textile/> Accessed 27 March, 2020; E. J. Alagoa, 'Long-Distance Trade and States in the Niger Delta' [1970] 11 (3), The Journal of African History, 319-329.

${ }^{6}$ N. Briggs et al (eds) (n19), 50-66; K. E. Orji (n5), 40-42; E. J. Alagoa (1970 [n84]), 319-329..

${ }^{7}$ N. Briggs et al (eds) (n19), 61-63; E. J. Alagoa (1970 [n84]), 319-329. Stanley Museum of Art, University of Iowa, 'Art \& Life in Africa: Benin Kingdom'<https://africa.uima.uiowa.edu/peoples/show/Benin+Kingdom> Accessed 27 March, 2020.
} 
In terms of external relations across the Atlantic, beginning with the Portuguese, Ancient Grand Bonny Kingdom established foreign relations with the early Western European discoverers, visitors and merchants that had contact with the Kingdom. The Kingdom's foreign relations with the Portuguese ${ }^{1}$ resulted in the exchange of Ambassadors between the Kingdom and Portugal in the $15^{\text {th }}$ Century (about $\left.1450 \mathrm{AD}\right){ }^{2}$ At the time, Bonny Kingdom's Ambassador to Portugal was its Aboriginal Prince Babaya-Asimini (also referred to as Abagy, Abazie and Ebi), ${ }^{3}$ son of King Asimini (younger brother of our King Alagbariye), who was chosen on a harmonious basis by King Alagbariye, King Asimini and other leading members of the Founding Ancestors of the Kingdom, namely Amadapu. The Amadapu or Aseme-Amadapu were rulers of aboriginal royal pedigree and next to the Monarchs in the Kingdom's hierarchical form of rulership. On the whole, the Amadapu of the Kingdom are successive blood descendants and heads of the blood descendant Major houses of the Founding Group, namely heads of Duawaris.

By and large, it was during the era of the Founding Ancestors (the Founding Generation, otherwise called the Ancient Landmarks) of the Kingdom, which coincided with the reign of the Premier category of Monarchs, that the civilisation (including its commonwealth) of the Kingdom was established as a heritage for succeeding generations (of the Kingdom). Put differently, it is the Premier category of Monarchs, along with the rest of the Founding Ancestors of Ancient Grand Bonny Kingdom that established the Kingdom's civilisation (including its commonwealth), which became the heritage of succeeding generations of the Kingdom. ${ }^{4}$

Essentially, it is clear from this sub-heading of the study that the foundation of good governance (GG) was laid during the reign of the Premier category of Monarchs considered here, and that at the time governance was based on harmonious and unanimous decisions made by the homogeneous founding kindred group of the Kingdom. GG at the time was distinctively based on selflessness, characterised by responsible stewardship of the four Premier Monarchs of the Kingdom, as exemplified by the reign of King Alagbariya and the succeeding administration of King Asimini.

\subsection{The Second Category of Monarchs of Bonny Kingdom}

The second category of Monarchs of Ancient Grand Bonny Kingdom is made up of the eight direct or immediate successors of the four Founding Fathers, Patriarchs and Premier Monarchs. This category of Monarchs starts from King Edimini to King Halliday-Awusa.

\subsection{The Third Category of Monarchs of the Kingdom}

The third category of Monarchs of Bonny Kingdom are the eleven Monarchs after King Halliday-Awusa, namely from King Perekule to the incumbent King Edward Asimini William Dappa Pepple. ${ }^{5}$ The admixture to this group is King Adumtaye-Bereibibo, who was paramount head of the Bristol-Alagbariya royal house before he became the Monarch of the Kingdom. ${ }^{6}$

4. Case Studies of Alagbariya, Asimini and Awusa as Selfless Monarchs of Ancient Grand Bonny Kingdom It has already been established that Premier Aboriginal Kings Opuamakuba, Alagbariya, Asimini and their cousin, Ndoli-Okpara, were the Patriarchs of Ancient Grand Bonny Kingdom, who were the first four Monarchs of the Kingdom. It has also been highlighted that these first four Monarchs of the Kingdom belong to the first category of Monarchs, whom succeeding Monarchs of the Kingdom are basically their successors in title and/or office. Among the three categories of Monarchs, King Awusa (otherwise called Halliday-Awusa) was identified as the last of the second category of Monarchs, who were eight in number. On this note, we shall proceed to reflect on the exemplary leadership qualities of King Alagbariya, Asimini and Halliday-Awusa of Ancient Grand Bonny Kingdom.

\subsection{Premier High-Priest and Aboriginal King Alagbariya as a Selfless Monarch of Ancient Grand Bonny Kingdom}

This sub-heading would be better discussed under the following: (i) 'The Name Alagbariya (Founder of Grand Bonny and A Profound Hunter): In Relation to the Natural Royal Status of the Founding Ancestors of Bonny

\footnotetext{
${ }^{1}$ K. E. Orji (n5), 42.

${ }^{2}$ Cloudpedia (n41): The Oracle Newsletter (of 17 October, 2017), 'Bonny-Bodo Road: NLNG Pushes CSR Limits, Reconnects Life' $<$ https://oraclenews.ng/bonny-bodo-road-nlng-pushes-csr-limits-reconnects-life/> Accessed 27 March, 2020.

${ }^{3}$ E. J. Alagoa and A. Fombo (n1), 7.

${ }^{4}$ Ibid.

${ }^{5}$ Programme of the $20^{\text {th }}$ Coronation Anniversary of His Majesty, Dr Edward Asimini William Dappa Pepple, III, CON, JP, Perekule XI, Natural Ruler and Amanyanabo of Grand Bonny Kingdom, 9 and 13.

${ }^{6} \mathrm{Ibid}$; E. J. Alagoa and A. Fombo (n1), 10-41, 49, 67 and 89.
} 
Kingdom and the Blood Descendants of these Ancestors', and (ii) 'Selfless Leadership of Premier Priest and Aboriginal King Alagbariya'.

\subsubsection{The Name Alagbariya (Founder of Grand Bonny and a Profound Hunter): In Relation to the Natural Royal Status of the Founding Ancestors of Bonny Kingdom and the Blood Descendants of these Ancestors}

Alagbariya (originally Alagbariye) was named after his blood ancestor, Ebeni (the progenitor of the Founding Ancestors of Ancient Grand Bonny Kingdom). The name Alagbariye (Alagbariya) is interpreted by some as meaning Aliagbariya, 'I am born into royalty' and consequently 'I am naturally royal', implies a God-given (divinely-endowed) royal heritage. Alagbariya's name thus establishes, collaborates and affirms that the royal status of the Founding Ancestors of Bonny Kingdom and their blood descendants is God-given and in effect inalienable. This implies that the God-given royal status of the blood descendants of the Founding Ancestors of the Kingdom, as blood descendants of these Ancestors is a matter of natural law as well as natural right and human right to inheritance. ${ }^{1}$ Based on the human right and fundamental freedom of peaceful assembly and association, the association of Duawaris (Founding and Aboriginal royal houses) of Ancient Grand Bonny Kingdom is the umbrella organisation of Major Aseme-waris ('main houses of Asemes ['houses/families of aboriginal royal status') of the Kingdom. ${ }^{2}$

Besides, Article 2 of the Universal Declaration of Human Rights (UDHR), 1948, provides that every member of the human family is entitled to all the rights and freedoms set forth in it, without distinction of any kind, such as distinction concerning the circumstances of birth of that individual. ${ }^{3}$ The UDHR has become an international 'Magna Carta' ('Magna Charter' ['great charter' of rights]) for all humanity (all persons everywhere around the world, including Nigeria and Nigerian citizens and citizen-groups). ${ }^{4}$ Thus, the UDHR prevails in Africa as the African Charter (Banjul Charter) on Human and Peoples' Rights, as well as in Nigeria as the African Charter on Human and Peoples' Rights (Ratification and Enforcement) Act, 2004, ${ }^{5}$ even more specifically as Chapter Four of the 1999 Constitution of the Federal Republic of Nigeria (CFRN) (as amended), which is captioned 'Fundamental Rights'. ${ }^{6}$ While considering the high pedestal nature of human rights above ordinary laws and in effect other rights of citizens in Nigeria, in the historic and celebrated case of Ransome-Kuti v AG Federation (1985), Kayode Eso JSC (as he then was) declared as follows:

fundamental human rights are rights which stand above the ordinary laws of the land and which in fact are antecedent to the political society itself. These rights constitute a primary condition to civilised existence, and what has been done by our (Nigerian) Constitution since independence is to have these rights enshrined in the Constitution so that the rights could be immutable to the extent of the non-immutability of the Constitution itself. ${ }^{7}$ Given that Alagbariya was a very adventurous, brave, courageous and profound hunter, who never missed his target in the course of shooting, the name Alagbariya in Ibani is also popularly likened to Alagba gbarigbariya, meaning 'the gun that never misses its target'. Thus, while describing the Foremost Patriarch (Founding Ancestor), Aboriginal High-Priest, Premier Monarch (Amanyanabo) of Ancient Grand Bonny Kingdom, as the founder of

${ }^{1}$ R. J. Berry (n53); J. Finnis (n52).

2 Article 20, UDHR, 1948, Articles 10 and 11, African Charter on Human and Peoples' Rights (Ratification and Enforcement) Act (Cap A9) LFN 2004; Section 40, 1999 Constitution of the Federal Republic of Nigeria (CFRN) (as amended), captioned 'Right to Peaceful Assembly and Association'.

${ }^{3}$ Article 2, UDHR, 1948, unequivocally provides thus: Everyone is entitled to all the rights and freedoms set forth in this Declaration, without distinction of any kind, such as race, colour, sex, language, religion, political or other opinion, national or social origin, property, birth or other status. Furthermore, no distinction shall be made on the basis of the political, jurisdictional or international status of the country or territory to which a person belongs, whether it be independent, trust, non-self-governing or under any other limitation of sovereignty; UN, 'Universal Declaration of Human Rights' $<$ https://www.un.org/en/universal-declaration-human-rights/> $<$ https://www.ohchr.org/EN/UDHR/Documents/UDHR Translations/eng.pdf $>$ Accessed 27 March, 2020; Articles 10 and 11, African Charter on Human and Peoples' Rights (Ratification and Enforcement) Act (Cap A9) LFN 2004; Section 42, 1999 CFRN (as amended), captioned 'Right to Freedom from Discrimination'.

${ }^{4}$ F. Klug, A Magna Carta for All Humanity: Homing in on Human Rights (Routledge 2015); UN, Universal Declaration of Human Rights (UN 2018).

${ }^{5}$ African Charter on Human and Peoples' Rights (Ratification and Enforcement) Act, No.3 1983, Cap A9 2004.

${ }^{6}$ Chapter Four, captioned 'Fundamental Rights', 1999 CFRN (as amended); $C / f$ the bifurcation of human rights in Nigeria, by virtue of the distinction between civil and political rights, and economic and socio-cultural (ECOSOC) rights in the country; O. W. Igwe and C. T. Emejuru, 'Appraising the Jurisprudence of the African Commission on Human and Peoples' Rights from 1995-2000 with Respect to the ESC and Solidarity Rights and its Legal Impact on the Status of Human Rights in Nigeria' [2014] 4 (4) International Journal of Business, Humanities and Technology, 155-162; O.W. Igwe, 'A Legal Assessment of the Positive Duties Imposed by Economic, Social and Cultural Rights in Nigeria' [2014] 3 (4) American International Journal of Social Science, 194-201, especially 194 and 201.

${ }^{7}$ Per Kayode Eso JSC, in Ransome-Kuti v AG Federation [1985] Nigerian Weekly Law Reports (NWLR) (Part 60$) 221$. 
Grand Bonny, K. O. Dike describes Alagbariye as follows:

According to tradition, a famous chief and hunter, Alagbariye, on his expedition to the coast, came upon the site on which Bonny now stands, and aware of its potentialities for directing the new trade, brought his people to found the town. ${ }^{1}$

Also, among many historical records, such as archival records, historians, history books and historical commentaries on Alagbariya, few may be mentioned here. As E. J. Alagoa and A. Fombo put it,

Alagbariya is, however, known in Bonny traditions as Amakoromabo, meaning 'the founder. ${ }^{2}$

K. I. Abbey simply states as follows:

Ibani traditions of origin maintain that Alagbariye is the founder of Bonny. And he is referred to by the Ibanis as 'Amakoromabo' which means 'Founder.'

G. Finapiri also describes Alagbariya with the following soothing caption:

The Great Founder of the Ibani Kingdom, King Alagbariye $(1354-1486) .{ }^{4}$

The words of B. Benatari are simply, precisely and squarely put as follows:

The ancestor Kala-Beni (alias Alagbarigha), collective ancestor of the Ibani and Opobo Clans. ${ }^{5}$

On its part, the Bonny Kingdom Council of Traditional Rulers, represented by the Bonny Chiefs' Council/Amanyanabo-in-Council (King-in-Council), simply asserts as follows: 'Alagbariye (Amakoromabo)' ${ }^{6}$

Accordingly, the Bonny Kingdom Historical Society clearly and unequivocally states that

Alagbaria, being a hunter, usually ranged far and wide. During one of his hunting expeditions, he discovered a vast land full of curlew birds 'Okolo', and on his return told this to his fellow Ibani settlers. The newfound land by Alagbaria became known and called "OKOLOAMA", land of the curlews."

${ }^{1}$ K. O. Dike (n9), 24 and 196; E. J. Alagoa et al (eds) (n36), 262-263. K. O. Dike was one of the foremost crusaders of African nationalism, pioneer Nigerian historian, erstwhile Director of Institute of African Studies at the University of Ibadan, a onetime Vice Chancellor of University of Ibadan and a prolific writer.

${ }^{2}$ E. J. Alagoa and A. A. Derefaka (eds) (n23), 7; Government of the Federal Republic of Nigeria, ... of the four original founders, three - ALAGBARIA, OPUAMAKUBU, and ASIMINI - are stated to have come from the IJAW country. ... At Orupiri, where they settled and multiplied, ...From there, ALAGBARIA one day went hunting in a small canoe and landed at a certain spot, where there were large numbers of birds and game. Finding that this was good land for human habitation he returned and so informed his fellow tribes-men. After Inspection, they decided to move there and having cleared the land and built houses, they shortly after moved to the spot and named it OKOLOAMA (Okolo-Ama town, Curlew Town, so called from the numerous curlews there). Later this became known as Bonny, Government of the Federal Republic of Nigeria, Intelligence Report on Bonny District, Owerri Province [1960] MINOG, marked File No. EP 8691, 6/1/60, paragraphs 17-19, 7; T. A. Osae and S. N. Nwabara, 'Bonny was founded by a great hunter called Alagbariya', T. A. Osae and S. N. Nwabara, A Short History of West Africa (London University Press 1968), 147; E. T. Bristol-Alagbariya (2010 [n7]), 106 -107; E. T. Bristol-Alagbariya (2013 [n36]), 101-103; Unreported Consent Judgment in Suit No. PHC/399m/2002, between Bristol-Alagbarigha royal house (Founder of Grand Bonny) $v$ The Shell Petroleum Development Company of Nigeria Ltd (SPDC), given on 9 June, 2010, by the Hon. Justice Ben E. Ugbari; Unreported Consent Judgment in Suit No. PHC/573/2011, between Bristol-Alagbarigha royal house (Founder of Grand Bonny) v Nigeria LNG Limited, given on 30 April, 2012, by the Hon. Justice T. A. Oji.

${ }^{3}$ K. I. Abbey (n36), 1.

${ }^{4}$ G. Finapiri, Forgotten Heroes of Grand Bonny (CSS Press 2001) v, 7-9.

5 B. Benatari, 'The Ijo Genesis: The Original Ancestors and the Genesis of the Ijos' (October 2006) $<$ http://www.bayelsa.org.uk/main/ijaw-genes $>$ Accessed 26 July, 2013; The London-based Ijaw People's Association of UK and Ireland, 'The Ijaw Genesis (A Short Discourse); The Pointer (of Monday, February 24, 2020), 'The Ijaw People: Earliest Inhabitants In Southern Nigeria?' $<$ https://thepointernewsonline.com/?p=38648> Accessed 27 March, 2020.

${ }^{6}$ Bonny Chiefs' Council/Amanyanabo-in-Council of Bonny Kingdom, 'Farewell Ceremonies for His Royal Majesty, Captain Opuada Secondus Pepple, King Perekule II, Amanyanabo of Bonny [1996] Bonny Chiefs' Council/Amanyanabo-in-Council of Bonny Kingdom, 4; Programme of the 20th Coronation Anniversary of His Majesty, Dr Edward Asimini William Dappa Pepple, III, CON, JP, Perekule XI, Natural Ruler and Amanyanabo of Grand Bonny Kingdom, 9.

${ }^{7}$ Bonny Kingdom Historical Society (n4), 20 and 50. There are numerous other references to Alagbariye as the founder of Grand Bonny, of which the following are few: E. J. Alagoa, Alagbariye, who came down from Azumini creek and settled at Okuloma (Okoloama), E. J. Alagoa (2005 [n36]), 151-152; O. Y. Buowari, The Ibani people migrated from the Central Delta due to numerous wars. Among the leaders of this migration were Upuamakuba and Alagbariya, they went along with their families. They and their followers moved to the Ndoki area. Along this route some men stayed behind at Azuogu and Asobie, all in the Ndoki axis. Alagbariya was a hunter and high priest and he hunted everywhere in the whole region during his hunting adventure. On one of his expeditions, he saw curlew birds in large numbers. A curlew is a bird with long legs and a long beak that lives near water. On returning home, he told his people that he had found a fine spot fit for human settlement, and so many people followed him and a town emerged from there. ... Alagbariya is one of the Founding Fathers of Grand Bonny Kingdom and the Founder of the Bristol-Alagbariya House. ... Alagbariya: Founder of Grand Bonny Kingdom, O. Y. Buowari (n36), 78 and 189; C. T. C. Ennals (Assistant District Officer), The section under Alagbariye, the First King of Bonny, and the Founder of the present Bonny House of Bristol, proceeded south through Opoku (in Ogoni country) and Essene, reaching finally the Site they called Okoloama (the land of the curlews) or Bonny, C. T. C. Ennals (Assistant District Officer) (n36), paragraph 24, 9; Federal Ministry of Education, , Government of the Federal Republic of Nigeria, This Monarch was the Patriarch and Chief of the Obani or Ancient Bonny Hordes, that migrated from the interior and finally made a permanent settlement in the Island 
The foregoing and many other historical references as well as case-law exist, which refer to Alagbariya as the discoverer, founder and first indigene of Grand Bonny as well as the Leader, Founding Father, Patriarch, Premier High Priest and Aboriginal Monarch of the Grand Bonny Kingdom.

\subsubsection{Selfless Leadership of Premier Priest and Aboriginal King Alagbariya}

As a leader of the Founding Group of Ancient Grand Bonny Kingdom and Premier High-Priest ${ }^{1}$ and Aboriginal King, Alagbariya, was magnanimous and selfless throughout his life and times. Alagbariya's public-interestoriented leadership characterised his activities and entire life. Due to his public-spirited, visionary, brave, dynamic and strategic leadership qualities, even his elder brother, Opuamakuba, personally acknowledged and appreciated him as the foremost leader of the team and their entire generation. Hence, in his accolade, the Founding Generation, described him as a hunter per excellence, and therefore nicknamed him Alagba gbari gbariya, a hunter, who never missed his target in the course of his hunting expeditions'.

Even though he was the leader of the team, he (as a God-fearing and public spirited individual) respected his elders, and as such his elder cousin (Ndoli-Okpara) and his elder brother, Opuamakuba, ruled and reigned before he assumed the throne of kingship in the Kingdom. ${ }^{2}$

Furthermore, as a selfless leader, he voluntarily facilitated the surprising, fundamental, painful and supreme sacrifice of offering his daughter, Princess Osunju Alagbariya, to the land and fresh water deities, so as to obtain good drinking water in Grand Bonny and peace in the Kingdom, which required blood sacrifice of a Virgin Crown Princess. According to the belief of the time, based on the form and other details of the sacrifice to be made, a Virgin Crown Princess of the Kingdom was required by the deities. Aboriginal Virgin Crown Princess Osunju Alagbariya was thus sacrificed for the peace, development, growth, survival and sustenance of the Kingdom. ${ }^{3}$

Even as apex leader, namely Monarch (Amanyanabo and High-Priest of Ikuba (national war deity of the Kingdom), Alagbariya's decisions were unanimously and harmoniously reached with other leading members of the Founding Group and the voice or voices of reason of the rest of the Founding Ancestors of the Kingdom. ${ }^{4}$ Thus, at the time, Alagbariya's reign as Monarch was based on his unparalleled display of the spirit of brotherhood, concord and public interest, aimed at the unity, common progress, stability, overall wellbeing and sustainability of the Kingdom. It was on this note that Alagbariya led his land route founding team to passionately negotiate with and convince his blood relatives, members of the Kongo Lineage, who had established Ikpakpayo (Finima Community, now known as Old Finima Community) to become members of Bonny Kingdom. The result of the passionate negotiation, a mutual agreement, was that members of the Kongo Lineage became a common and united Founding Group together with the Alagbariya group. It was at this time that the aboriginal wards (lineages) of the Kingdom became five in number. ${ }^{5}$

Ultimately, to demonstrate his good and unparalleled leadership further, during the arrival of the Portuguese explorers, visitors and traders in the $15^{\text {th }}$ Century AD, it was (according to the belief of the people at the time) said that another human sacrifice would be made to the deities of the Bonny sea, to widen the sea, to enable ships visit Bonny regularly from the Atlantic Ocean thereof, for purposes of external relations, particularly external trade, which started between the Portuguese and Bonny Kingdom. Based also on the form and other details of the sacrifice to be made, another Virgin Crown Princess of the Kingdom was required by the deities of the sea. Alagbariya had to persuade his younger brother, Asimini, to offer his daughter. Accordingly Asimini agreed to do

or Clusters of Islands known by the several distinctive names and appellations of Ocoloama [Okoloama], Obani or Bonny. ... the Portuguese early discoverers called it Bonny or more strictly speaking - Grand Bonny, Federal Ministry of Education, Government of the Federal Republic of Nigeria (n36); M. A. G. Leonard (n36), 23-24 and 47; B. A. Obuoforibo (n36), 259; G. I. Jones (n2), 110, 128 and 198.

${ }^{1}$ When Alagbariya was King, religion and public sector governance was intertwined. Thus, in accordance with the belief of people of the Kingdom at the time, although they knew 'Tamuno' ('God Almighty' ['Sonakirinateme Tamuno: 'God Almighty, The Creator of Heaven and Earth') as the Ultimate Supreme Being, they had a traditional religion based on worship of Ikuba, their national god and war deity. Alagbariya served as High-Priest of Ikuba. The worship of Ikuba ended with the introduction of Christianity in 1861, by King William Dappa Pepple (the Kingdom's Seventeenth Monarch, who belonged to the third category of Monarchs identified in this study). E. J. Alagoa and A. Fombo (n1), 6, 9, 13-14, 24-27, 75, 76 and 89; O. Y. Buowari (n36), 4, 7, 65, 71, 120-121, 124-127, 139, 149, 162, 165, 170-171 and 191.

${ }^{2}$ E. J. Alagoa and A. Fombo (n1), 6; Bonny Kingdom Historical Society (n4), 49-50.

${ }^{3}$ E. J. Alagoa and A. Fombo (n1), 7; Bonny Kingdom Historical Society (n4), 50.

${ }^{4}$ Holy Bible, Isaiah 1:18; Proverbs 4:7; Proverbs 4:7, 8:15-17, 9:10; A. Rand, The Voice of Reason: Essays in Objectivist Thought: 5 (Penguin 1990), 3-6.

${ }^{5}$ E. T. Bristol-Alagbariya (2010 [n7]), 109; c/f G. I. Jones (n2), 198. 
so, while Alagbariya promised to hand over the reins of kingship to Asimini. Asimini thus presented Virgin Crown Princess Ogbolo Asimini, who became offered to the deities of the sea, for the Bonny River to widen, and thereby boosted external relations, particularly external trade and commerce between the Portuguese and Bonny Kingdom. ${ }^{1}$ In the words of E. J. Alagoa and A. Fombo, after the sacrifice of Aboriginal Virgin Crown Princess Ogbolo Asimini, 'the [Bonny] river gradually widened, and ships began to visit Bonny regularly for trade.'2

Forthwith, Alagbariya had to stand gallantly in an international style, to crown his brother, Asimini, with a new Portuguese branded crown. Hence, some inexhaustibly refer to Asimini as the first crowned King. ${ }^{3}$

Lessons from the reign of Alagbariya thus demonstrate that a good leadership attribute is to keep to promises made in public interest, as Alagbariya personally upheld and singularly enforced his promise to ensure that his brother, Asimini, succeeded him, while he (Alagbariya) was still alive and awake to his responsible stewardship as the Premier High-Priest of the Kingdom.

Furthermore, when Asimini had become King, Alagbariya harmoniously joined him to muster courage and support, to ensure King Asimini's son, Aboriginal Prince Abagy, became Bonny Kingdom's Ambassador to Portugal in the late $15^{\text {th }}$ Century AD. ${ }^{4}$

Thus, while referring to King Alagbariye $(1354$ - 1486) as 'The Great Founder of the Ibani Kingdom, an outstanding Ibani historian and prolific writer, G. Finapiri, had a little more to say about him in the following manner:

... Though Alagbariye gave up the throne to Asimini because of the rigours of the time, he still stands out as the true founder of the Great Ibani Kingdom, and the impression produced are those of a lofty sense of integrity, power and unparalleled elevation. ${ }^{5}$

Alagbariya certainly displayed unparalleled characteristics of good leadership based on yet benchmarked service and unsurpassed stewardship to the people, as well as dignified transparency and accountability in decisionmaking and decision-implementation processes, all done in the overall interest of the homogeneous people of the Kingdom. He displayed genuine and positive leadership on the basis of legitimacy, strategic vision (in the exercise of authority), consensus orientation, equity and inclusiveness (involving partnership between governance and its followership), responsiveness, clarity, coherence, harmony, predictability, solidarity, discretion, determinacy, symbolic validation, adherence, authorisation and harmonious sustainability of tenure. Alagbariya laid, promoted and sustained even more, the foundation of good governance qualities of his predecessors (Kings Ndoli-Okpara and Opuamakuba).

\subsection{Sustained Selfless Public Leadership Style of Premier King Asimini}

King Asimini showed utmost respect to his elder brother, Alagbariya, whom he succeeded as King. Like his consanguineal kith and kin and predecessors, King Asimini rendered stewardship to the people, such that many are of the opinion that service to the people of the Kingdom reached its apex during his reign. Thus, as E. J. Alagoa and A. Fombo put it,

... the principle of service [to the people and the Kingdom] reached its highest point in Asimini. ${ }^{6}$

King Asimini continued public-spirited services of traditional leadership to the people of Ancient Grand Bonny Kingdom, by maintaining responsible stewardship in such ways as sustaining harmonious decision-making and decision-implementation processes, which involved his immediate subordinate category of rulers (the 'Amadapu'). $\mathrm{He}$ also listened to the voices of reason of the generality of Bonny kingdom's homogeneous (blood related) kindred group during his reign, and thereby consolidated on rendering quality service to the people and the entire Kingdom. Consequently, as already indicated above, according to the belief of the time, he accepted the request of his elder brother and predecessor, Alagbariya, to present his daughter, Aboriginal Virgin Crown Princess Ogbolo, 'as a sacrificial lamb', to the estuarine deities, to open-up of the Bonny River, for purposes of promoting external relations. These relations included external trade and commerce, which was strengthened between the Portuguese and the Kingdom, during his reign. External relations, especially external trade and commerce, are still ongoing from the Bonny Atlantic coast, for the benefit of Nigeria, especially in the course of petroleum development

\footnotetext{
${ }^{1}$ E. J. Alagoa and A. Fombo (n1), 7.

${ }^{2}$ Ibid.

${ }^{3}$ Programme of the $20^{\text {th }}$ Coronation Anniversary of His Majesty, Dr Edward Asimini William Dappa Pepple, III, CON, JP, Perekule XI, Natural Ruler and Amanyanabo of Grand Bonny Kingdom, 13.

${ }^{4}$ Cloudpedia (n41); The Oracle Newsletter (of 17 October, 2017) (n88).

${ }^{5}$ G. Finapiri (n36), 7-9, particularly 9.

${ }^{6}$ E. J. Alagoa and A. Fombo (n1), 15.
} 
operations in the oil-rich Delta region and other oil producing areas of the country.

Certainly, if any, only an exceptional handful, among countless leaders, would accept to sacrifice their own blood (Aboriginal Virgin Crown Princesses, who may succeeded them), the way and manner the Founding Fathers, Patriarchs and Premier Kings Asimini and Alagbariya did, for the good and wellbeing of all as well as for the overall progress of their Kingdom (the Ancient Ibani nation). Hence, while referring to the generosity and enormous personal sacrifices made by the duo (Founding Fathers, Patriarchs and Premier Monarchs of Ancient Ibani nation, Alagbariya and Asimini), for the good of the Kingdom and Bonny [Ibani] people, O. Imoagene succinctly states as follows:

Alagbariye's act of sacrificing his daughter to the fresh water deities to procure good drinking water for his people, endeared him to them. ... He is generally referred to as the founder and ancestor of Bonny. ... The founding father [of Bonny], Alagbariye, [and his younger brother, Asimini] were said to have made personal sacrifices for the good of the people [of Bonny Kingdom]. ${ }^{1}$

Thus, the invaluable personal, supreme, painful and overwhelming blood sacrifices of the Kingdom's Aboriginal Virgin Crown Princesses Osunju Alagbariya and Ogbolo Asimini for the peace, development, growth, survival and sustenance of the Kingdom and Nigeria (at large), presently in the course of petroleum resources development operational activities and thus blood oil and blood gas development operations in the Kingdom, qualify Alagbariya and Asimini as incomparable selfless leaders of Ancient Ibani nation at all times and for all genuine public-spirited purposes.

The duo, Alagbariya and Asimini, remain good and yet incomparable Founding Fathers, Patriarchs and Premier Monarchs of the Ibani nation, who displayed benchmarked good leadership qualities and public-spiritedness per excellence, over and above their well-founded and God-given legitimate personal interests. They remain in the annals of the history of Ancient Ibani nation, as second to none Star Leaders, First Class and therefore Greatest Monarchs of the Ancient nation, whom successive Monarchs and other leaders of the Kingdom and beyond should study and emulate, towards a better present and greater future of Ancient Ibani nation, modern Nigeria, the African Continent and the worldwide black race.

Indeed, during the era of Premier Kings Ndoli-Okpara, Opuamakuba, Alagbariya and Asimini, the Monarchical institution of Ancient Grand Bonny Kingdom was originated, stable, sustainable, as a classic institution of African civilisation. Consequently, the characteristic features of good governance, such as leadership based on unparalleled service to the people (namely service to the people centred on responsible and yet unsurpassed stewardship), inherent goodwill, transparency and accountability in decision-making and decision-implementation processes amounting to partnership in governance, as well as legitimacy, strategic vision, consensus orientation based on fair-play, responsiveness, predictability, coherence, integrity, harmonious disposition and sustainability of tenure, were firmly established during the era of the Kingdom's Premier Monarchs, as noted earlier, while discussing the life and achievements of King Alagbariya. These four Monarchs practised GG, based on yet unsurpassed responsible stewardship to Bonny people and entire Bonny Kingdom. They may be described as exemplary leaders and rulers per excellence, who knew that power and authority in the disposition of humans are transient. ${ }^{2}$ They $^{2}$ knew the relationship between leadership and service to the people and overall public interest, as well as the relationship between leadership power and morality. They exercised their natural right of leadership with restraint and thereby ensured that power and authority were exercised gently and rationally between them and their subordinates, the component traditional rulers of the Kingdom, known as Amadapu. They ruled and reigned jointly with the Amadapu and the rest of the Founding Group, which means sharing power and authority in search of any salient 'voice' or 'voices' of reason, in the course of all-embracing decision-making and decision-implementation processes, while bearing the ultimate burdens of leadership, in such forms as the supreme, painful and overwhelming blood sacrifices of Aboriginal Virgin Crown Princesses Osunju Alagbariya and Ogbolo Asimini, for the peace, development, growth, survival and sustenance of the Kingdom. Based on inviolable natural law and its associated inalienable natural right to succession of the exalted throne of kingship, they succeeded in setting an unprecedented stage for smooth, harmonious and stable succession by laying a formidable foundation that institutionalised kingship as their collective heritage along with the rest of the Founding Ancestors of the Kingdom. It was on the platform of natural right inherent in natural law that Queen Kambasa returned to Bonny after her

\footnotetext{
${ }^{1}$ O. Imoagene, Peoples of the Cross River Valley and Eastern Delta: Know Your Country Series Handbook of Nigeria's Major Culture Areas (New Era Publishers 1990), 26 and 50.

${ }^{2}$ Holy Bible, Psalm 62:11, which provides that 'God has spoken once; I have heard this twice: that power belongs to God'; Revelation 19:1, which states as follows: After this I heard a sound like the roar of a great multitude in heaven, shouting: 'Hallelujah! Salvation and glory and power belong to our God!.
} 
marriage to assume the throne of a Monarch, by seizing an ivory tusk (staff of office [Odu]) bearing the name of her father and predecessor, Edimini, even after being married to Opoli of Azuogu of Ndokiland, and became the first and only woman to occupy the throne of kingship, ${ }^{1}$ and thereby established a legacy for her blood descendants and their future generations, in a manner that merits being examined as an independent study, which is capable of contributing to the worldwide knowledge industry.

For so institutionalising and preserving a common heritage established on natural law and natural right to leadership for themselves, the rest of the founding ancestors and their future generations, the four Founding Fathers, Patriarchs and Premier Monarchs of Ancient Grand Bonny Kingdom established a fundamental path to safeguard their respective and collective future generations from being discriminated against, arbitrarily undermined, flagrantly abused and egregiously subjugated in the Kingdom, contrary to dictates of natural law and its accompanying natural right and eventual human rights, as fall-outs of natural right. ${ }^{2}$

Besides, the era of these four Premier Monarchs of Ancient Grand Bonny Kingdom may thus be described as the ultimate period of the yet unsurpassed good traditional governance (GTG), when Kingship was in all ramifications simply based on public-spiritedness in the form of excellent traditional government social responsibility (TGSR), towards overall wellbeing of the people, houses and entire Ancient Ibani nation. In the process, Ancient Ibani nation (Bonny Kingdom) assumed the status of a landmark primordial Nigerian nation as well as an exemplary, enviable and formidable model of early African civilisation.

Consequently, the second category of Monarchs, who were eight in number, had truly, duly and conscientiously been schooled to imbibe and practise the ethical norms, values and pragmatic disposition of stabilising and sustaining TGSR embedded in GTG, towards overall public good in Ancient Ibani nation.

\subsection{King Halliday-Awusa's Characteristic Selfless Leadership Qualities Learnt from His Ancestors and Predecessors}

King Halliday-Awusa, who is also known as King Awusa, King Halliday or King Holiday (the King on Holiday), ${ }^{3}$ was a noble, very unassuming and public-spirited Monarch of Grand Bonny Kingdom. These qualities enabled him to rule the Kingdom and reign thereof as an exemplary successor of his predecessors and remarkable blood descendant of the Founding Ancestors of the Kingdom. Thus, the reign of King Awusa was characterised by service to the people towards the wellbeing of the kingdom and its sustainability as a primordial African sovereign state.

In particular, the era of King Awusa witnessed the controversial Bonny-Andoni seven years' war, which took place towards the beginning of the $18^{\text {th }}$ Century AD. As the primary burden of prosecuting this War was on the King, he did his best in the interest of Bonny Kingdom. However, the royal treasury significantly depleted about the sixth year of the War. In the process, the king accepted the advice of his niece, Princess Okuru, who was also a blood descendant of the Founding Generation of the Kingdom. Princess Okuru had introduced Perekule, a nobleman of the Kingdom, with whom she had an intimate love affair, to her uncle, King Awusa. She told the King that Perekule was a wealthy nobleman of Bonny Kingdom, who had the interest of the Kingdom at heart and would thus be able to assist in prosecuting the War in favour of the Kingdom. Princess Okuru also negotiated with Perekule. She informed Perekule about her advice to her uncle (King Awusa), and that the decision reached was that in the event of the victory of Bonny Kingdom, the king had agreed that Perekule would succeed him. In return, Perekule accepted to marry Princess Okuru, if King Awusa eventually handed over kingship to him.

Perekule was a blood descendant of Premier King Asimini, through Queen Kambasa (Kampayo-ofori), Papanye and Siriye. ${ }^{4}$ Perekule was a very rich merchant, who traded in ivory tusks, spices and various other items, during the era of the Atlantic trade in slaves in the Ancient Eastern Niger Delta region area of Bonny Kingdom. Consequently, the programme of the $20^{\text {th }}$ Coronation Anniversary of His Majesty, King Edward Asimini William Dappa Pepple, provides some information about King Halliday-Awusa and King Perekule. In answer to the question, Who was King Perekule?, the said programme features the following answer:

Biriye, a Bonny noble, begat Papanye by Queen Kambasa. Papanye in turn begat Siriye, who begat Perekule or Captain Pepple 1. King Perekule was a very rich merchant, trading in ivory tusks, spices and various other items. ${ }^{5}$

\footnotetext{
${ }^{1}$ E. J. Alagoa and A. Fombo (n1), 8-10; R. J. Berry (n53).

2 J. Finnis (n52); C. F. Alford (n52); Y. Olomojobi (n52), 2.

${ }^{3}$ H. Crow, Memoirs of the Late Captain Hugh Crow of Liverpool: The Life and Times of a Slave Trade Captain (Bodleian Library/Oxford University Press 2007), 95.

${ }^{4}$ E. J. Alagoa and A. Fombo (n1), 10.

${ }^{5}$ Programme of the 20th Coronation Anniversary of His Majesty, Dr Edward Asimini William Dappa Pepple, III, CON, JP, Perekule XI, Natural Ruler and Amanyanabo of Grand Bonny Kingdom, 13.
} 
Accordingly, while answering the question 'Who was King Awusa or King Halliday?, the above-stated programme puts forward the following answer:

King Halliday was the predecessor of King Perekule. King Halliday handed over the government of Grand Bonny Kingdom to King Perekule as a result of the seven years Bonny-Andoni War. ${ }^{1}$

According to E. J. Alagoa and A. Fombo, the seven years Bonny-Andoni War did not go all that well with Perekule, as he lost his two sons, Ibulu and Kuronchi, and he too was barely saved by Allison Nwaoju (also called AllisonNwaoju, Allison or Nwaoju), who was a ward of Perekule's daughter, Adumta. ${ }^{2}$ In their words,

... the great demands of the Andoni war are claimed as the occasion for King Awusa's abdication, and the enthronement of King Perekule. However, the war did not go all that well for King Perekule either. The King lost two of his sons, Ibulu and Kuronchi, and was himself barely saved from one engagement by the timely intervention of Allison Nwaoju (who thus won a chieftaincy title for himself and other deserving slaves). ${ }^{3}$

Ultimately, King Awusa honoured his promise to his cousin, Perekule, by entrusting the leadership vis-à-vis handing over the Kingdom on Perekule. ${ }^{4}$ By so handing over or entrusting kingship on King Perekule, King Awusa consolidated upon as well as complied with the impeccable distinctive and first class example of his predecessors and the rest of the Founding Ancestors, premised on natural law and natural right to succession to traditional leadership position in Ancient Grand Bonny Kingdom, particularly the office and/or title of kingship in the Kingdom.

Handing over of kingship (from one individual to another) was not a new phenomenon to the Founding Group of the Ancient Grand Bonny Kingdom, as this was done during the era of the four Patriarchs and Premier Monarchs, namely from Ndoli-Okpara to Opuamakuba, and thereafter from Opuamakuba to Alagbariya and then from Alagbariya to Asimini. On this note, it may be appreciated that kingship (Amanyanaboship) originated as a collective heritage of the Premier Monarchs of Bonny Kingdom in particular and that of the Founding Ancestors of the Kingdom in general. Thus, during the reign of the Kingdom's forenamed Patriarchs and Premier Monarchs, the features of collective ownership of and collective responsibility in the Kingdom were evident, as these features were clearly established for the future, particularly for future generations of the Founding Ancestors to learn from, even as a way to promote GTG in the Kingdom.

However, the handing over of kingship by King Halliday-Awusa to Perekule was somewhat controversial, as Perekule was engaged in prosecuting the seven years' Bonny-Andoni War from the sixth year of the War, but did not directly win the war. In the process, hostilities ended, which eventually led to the end of the War. Besides, the circumstances of the end of hostilities and the ultimate end of the War remain controversial between Bonny and Andoni till date. ${ }^{5}$

For purposes of this study, it would suffice to state that King Halliday-Awusa made a patriotic promise to hand over kingship to Perekule, and this promise was honoured, albeit conditionally. This may be considered so because while Halliday-Awusa 'kept back' the traditional staff of office of kingship (Odu: the instrument of power and authority of Amanyanaboship, with which the first twelve Monarchs of the Kingdom ruled) ${ }^{6}$ Amadabo Adapa Alagbariya proceeded to Crown Perekule as King, based on harmonious resolution of the matter by the blood descendants of Founding Ancestors of the Kingdom.

Focussing on the mainstream of this study, it is pertinent to mention that King Halliday-Awusa made a publicspirited promise to handover kingship to Perekule, which was actualised in a form of harmonious decision reached by the King and the Kingdom's apex decision-makers, all whom were blood descendants of the Founding Ancestors of the Kingdom. In the process, Amadabo Adapa Alagbariya (who was the head of the Alagbariya house) had to crown Perekule as king. In effect, the controversy that shrouded the handover of kingship from HallidayAwusa to Perekule is not that the latter (Perekule) was not eligible to be king. Certainly, as a blood descendant of Premier King Asimini (namely a nobleman of aristocratic descent [an Aseme] of Bonny Kingdom), ${ }^{7}$ and hence as a matter of natural law and natural right to leadership, backed by the aboriginal and thus superior custom of the Kingdom, Perekule was naturally eligible to become king or rather to assume kingship (in the Kingdom). In other words, if Perekule was not an Aseme, the discussion between King Halliday-Awusa and him (along with Princess

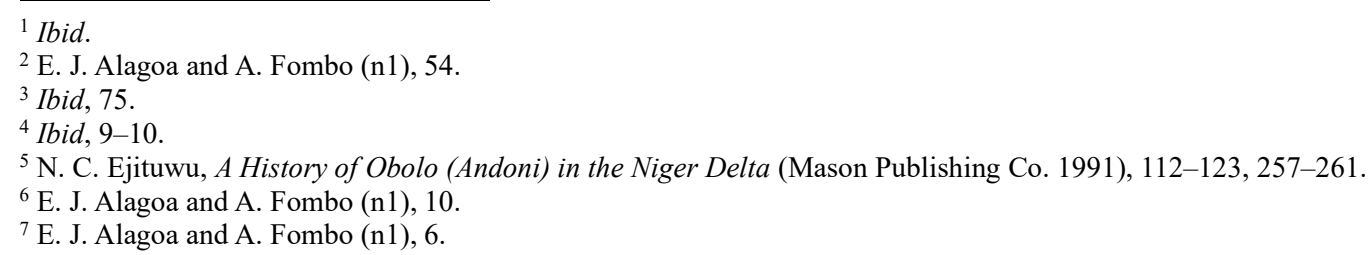


Okuru) about the transfer of kingship, would never have arisen or taken place, as he would not have been eligible to assume kingship in the Kingdom. ${ }^{1}$

Consequently, the heart of the controversy was whether or not Perekule should assume kingship, given the controversy concerning the circumstances that occasioned the end of hostilities and ultimate end of the War between Bonny Kingdom and Andoni; ${ }^{2}$ and these not being directly associated with this study, are hereby left for future studies.

However, to conclude this sub-heading, it may at this juncture be pertinent to highlight that the fact that Princess Okuru (Aseme-Orubo Okuru) was a part and parcel of Bonny Kingdom's core decision-making process during the reign of King Halliday-Awusa, as demonstrated by the event of Perekule's ascension to the position of kingship, confirms that Asemes (the blood descendants of the founding group) harmoniously governed the Kingdom at the time. Essentially, during the reign of King Halliday-Awusa, the principal rulers of the Kingdom were still the Amanyanabo (in the person of King Halliday-Awusa), the traditional High-Priest and Amadapu. However, while these three rulership positions continued to exist, they and their functions became diluted in the Kingdom; this later period of the Kingdom (namely from circa $18^{\text {th }}$ Century AD) may be characterised as when the term 'chief' and its accompanying nomenclature 'chieftaincy' and 'chieftaincy house' became in vogue, rather than the generic term 'house'. The period from about 1700AD onwards, when King Perekule assumed kingship, has thus been described by many as a turning point in the history of Bonny Kingdom. ${ }^{3}$ Nevertheless, no such turning point could kill out natural law and its inherent natural rights of the Asemes, as inalienable natural and human rights can only be supressed and not permanently annihilated. Annihilation of natural rights in Bonny Kingdom would involve dispossessing King Perekule's heritage from its inalienable 'Aseme' status, which emanated from natural law and its natural right to leadership. ${ }^{4}$ Such a dispossession would be contrary to natural law and thus arbitrary and therefore, at least, certainly impossible, if such arbitrariness is subjected to the rule of law, with particular regard to ongoing advancing trend of checkmating violations of civil rights and due process in society. ${ }^{5}$

\section{Natural Law, Good Governance and Lessons for Succeeding Monarchs of Bonny Kingdom and Overall Good Traditional Governance in the Oil-rich Niger Delta Region}

It is pertinent to examine this sub-heading under the following divisions: 'Natural Law and Good Governance' and then 'Lessons for Succeeding Monarchs of Bonny Kingdom and Overall Good Traditional Governance in the oilrich Niger Delta Region’.

\subsection{Natural Law and Good Governance}

Precisely, the natural law theory of law presupposes the divine origin of law and rulership (governance), ${ }^{6}$ particularly good governance (GG), as God Almighty provides for and/or caters for all His creations and governs them on the basis of certain precepts, namely divine laws, such as commandments, along with encouragements and admonitions. ${ }^{7}$ Natural law school of thought posits that moral principles, rules and standards should or ought to be characteristically embedded in laws governing human societies. ${ }^{8}$ Natural law relates to leadership (especially political leadership (governance), based on the divine roots and characteristic features of natural law, ${ }^{9}$ which

${ }^{1}$ G. I. Jones (n2), 56, 61-62, 128, 161, 172, 174, 176 and 202 as well as the table captioned 'Table 3: Structure and Political Alignments of Bonny Houses during the 19th Century', particularly 128; M. A. G. Leonard (n36), 23-24 and 47.

${ }^{2}$ N. C. Ejituwu (n129).

${ }^{3}$ E. J. Alagoa and A. Fombo (n1), 10-11 and 46.

${ }^{4}$ J. Finnis (n52); B. Tierney, The Idea of Natural Rights: Studies on Natural Rights, Natural Law, and Church Law $1150-1625$ (Wm. B. Eerdmans Publishing 1997); R. Tuck, Natural Rights Theories: Their Origin and Development (Cambridge University Press 1998); D. Boaz, 'From the Rights of Englishmen to the Inalienable Rights of All Men' $<$ https://www.cato.org/blog/rightsenglishment-inalienable-rights-all-men> Accessed 27 March, 2020.

${ }^{5}$ T. Sandefur, 'In Defense of Substantive Due Process, or the Promise of Lawful Rule [2012] 35 (1) Harvard Journal of Law \& Public Policy, 284-326.

${ }^{6}$ C. Roosevelt, The Science of Government, Founded On Natural Law (Nabu Press 2014); P. E. Sigmund, Natural Law in Political Thought (University Press of America 1981); Holy Bible, Psalm 11:4; 24:1; 47: 2 and 8; 103:19; 113:5; 115:3; Daniel 4:17 and 25.

${ }^{7}$ Holy Bible, Psalm 24:1; 1 Corinthians 10:26; Psalm 25:14; Genesis 17:1-2; Exodus 20:1-17; Deuteronomy 10: 4-20; Deuteronomy Chapters 11-13, Genesis 12: 2-4 and Proverbs 14:34 (b).

${ }^{8}$ A. Gomez-Lobo, Morality and the Human Goods: An Introduction to Natural Law Ethics (Georgetown University Press 2001); J. D. Breshears, Natural Law: The Moral Foundation for Social and Political Civility (CentrePointe Publishing 2016); M. H. Kramer, Where Law and Morality Meet (Oxford University Press 2004).

${ }^{9}$ The Holy Bible, Daniel 4: 6 and 26; Romans 13:1; Proverbs 29:2 and Philippians 4: 8-9; C. E. Rice, 50 Questions on the Natural Law: What It Is and Why We Need It (Ignatius Press 1999); J. Budziszewski (n3). 
features include the virtues of God such as love, righteousness, goodwill, selflessness, benevolence, transparency and accountability, as well as ethical behaviours of humans, such as fair-play, humility and commitment to duty, ${ }^{1}$ as these underscore the need for good traditional governance GTG in oil-rich Bonny Kingdom. By and large, the characteristic features of natural law have the potential to promote and enhance GG, including GTG, in societies, and oil-rich Bonny Kingdom is not an exception.

From the foregoing, natural law and by extension, natural rights and leadership based on natural law and natural rights, ${ }^{2}$ and GG are related, the same way as the past, present and the future are interrelated in the context of the subject-matter and discipline of history. ${ }^{3}$ Together, these have the potential of fostering and enhancing the foundation of GG, based on natural law and natural rights-oriented features of TGSR, established by the four Premier Monarchs of Ancient Grand Bonny Kingdom, namely Kings Ndoli-Okpara, Opuamakuba, Alagbariya and Asimini, and thereafter sustained up to the era of King Halliday-Awusa, in the form of selfless leadership. Watering of the seed of good and selfless traditional governance which existed from onset in Bonny Kingdom has the potential to boost sustained GTG and sustainable community development (SCD) in the Kingdom.

\subsection{Lessons for Succeeding Monarchs of Bonny Kingdom \& Overall Good Traditional Governance (GTG) in the Oil-rich Niger Delta Region}

The lessons of natural law as bedrock of good traditional governance (GTG) established by Ancient Grand Bonny Kingdom's four Premier Monarchs (Ndoli-Opara, Opuamakuba, Alagbariya and Asimini) and thereafter, sustained up to the era of King Halliday-Awusa, in the form of selfless leadership, are that succeeding Monarchs, other subsidiary leaders such as the chiefs, elders and titled citizens, should preserve, defend and continue to uphold the enviable good leadership legacies of the preceding Monarchs of the Kingdom. Considering the importance of the house system, as the core social system and pivot of life and society at large in Ancient Grand Bonny Kingdom as well as the key role of traditional rulership in the Kingdom, successive Monarchs (Amanyanapu) and their subordinate traditional rulers, namely the Country Chiefs (Se-Alapu), as well as the houses and entire people of the Kingdom should imbibe the exemplary traits and practices of GTG centred on selflessness, responsible stewardship and integrity, towards overall good, SCD in oil-rich Ancient Grand Bonny Kingdom, ${ }^{4}$ in the ongoing worldwide era of globalisation, especially economic globalisation, good governance (GG), and SD. ${ }^{5}$

It is important for successive traditional rulers of the Kingdom, especially the Monarchs and Country Chiefs (SeAlapu), who are next in the hierarchical rank of traditional rulership of the Kingdom, as well as other duly installed heads of the Kingdom's chieftaincy houses, to note that there is a social contract between government and the governed. ${ }^{6}$ In Nigeria, the social contract of governance is enshrined in the preamble and Section 14 (2) (b) of the 1999 Constitution of the Federal Republic of Nigeria (CFRN [as amended]), which provides that the security and welfare of the people constitute the primary purposes of government. The preamble of the Constitution also states

\footnotetext{
${ }^{1}$ Holy Bible, Philippians 4:8-9, which provides thus: Finally, brethren, whatsoever things are true, whatsoever things are honest, whatsoever things are just, whatsoever things are pure, whatsoever things are lovely, whatsoever things are of good report; if there be any virtue, and if there be any praise, think on these things. those things, which ye have both learned, and received, and heard, and seen in me, do: and the god of peace shall be with you; J. Budziszewski (n3); B. Shapiro, The Right Side of History: How Reason and Moral Purpose Made the West Great (Broadside Books 2019).

${ }^{2}$ J. Finnis (n52).

${ }^{3}$ E. H. Carr, What is History?; His Acclaimed Reflections on the Theory of History and the Role of the Historian (Penguin Books 1984); A. S. Abam, King Ibanichuka (Ado VI) 1816 - 1896: The Last of Okrika's Sovereign Rulers (Samag Stationery 2014), 1.

${ }^{4}$ R. K. Greenleaf and L. C. Spears (eds), Servant Leadership: A Journey into the Nature of Legitimate Power and Greatness 25th Anniversary (Paulist Press 2002); P. G. Northouse, Leadership: Theory and Practice (SAGE Publications 2016); A. Lincoln, Leadership Lessons of Abraham Lincoln: Strategies, Advice, and Words of Wisdom on Leadership, Responsibility, and Power (Skyhorse Publishing 2011); D. T. Phillips, Lincoln on Leadership: Executive Strategies for Tough Times (Warner 1992); L. K. Yew, From Third World to First: The Singapore Story - 1965-2000 (Singapore and the Asian Economic Boom) (HarperCollins Publishers 2000); J. T. Wren (ed), The Leader's Companion: Insights on Leadership Through the Ages (The Free Press 1995); G. Robert, Concise 48 Laws of Power (Profile Books 2002); A. Churchill et al, 'Spotlight on Leaders: What is Stewardship, and should all great leaders practice it?' $<$ https://nytimesineducation.com/spotlight/what-is-stewardship-andshould-all-great-leaders-practice-it/> Accessed 27 March, 2020.

${ }_{5}^{5}$ J. F. Sachs, The Age of Sustainable Development (University of Columbia Press 2015); B. C. Smith, Good Governance and Development (Palgrave Macmillan 2007); Achebe C., The Trouble with Nigeria (Fourth Dimension 1983) particularly 1-3.

${ }^{6} \mathrm{McCombs}$ School of Business, 'Social Contract Theory' $<$ https://ethicsunwrapped.utexas.edu/glossary/social-contracttheory> Accessed 27 March, 2020; K. Nweke and J. O. Nkwede, 'The Nigerian State and Hobbes' Social Contract Theory: An Albatross around the Collective Will of the People' [2019] 152 (3) European Journal of Scientific Research, 304-321; E. T. Bristol-Alagbariya (2013 [n36]), 251 and 261.
} 
that its purposes are to promote good governance (GG) and the welfare of all persons in the country. ${ }^{1}$ Embedded in the social contract of governance is GSR. Most importantly, every throne of rulership is established on righteousness and righteousness exalts a nation and its people. ${ }^{2}$ Consequently, the norms, ethical values, standards and exemplary practices associated with the social contract of governance, GSR and its accompanying features of goodwill, integrity, responsible stewardship towards overall public good and other characteristic features of GG ingrained in GG, apply to all forms of government, including traditional governments (traditional rulership), which should sensitise and persuade successive apex traditional rulers of Bonny Kingdom, to imbibe and practise the GTG, based on TGSR in the Kingdom, towards GTG and SCD in the Kingdom.

By and large, the planting and watering of GTG and SCD in any of the oil-rich minority ethnic Kingdoms, ethnic nationalities and areas of the Niger Delta region has the potential of boosting GTG and SCD in the rest of the oilrich areas and communities of the oil-rich Delta region and other oil producing areas of Nigeria. ${ }^{3}$

\section{Sustainable Community Development (SCD) in Oil-rich Bonny Kingdom}

Oil-rich Ancient Grand Bonny Kingdom has been playing host to multinational business organisations (corporations $[\mathrm{MNCs}]$ ) in the course of history. The Kingdom has been playing this role since the $15^{\text {th }}$ Century, from the period of the arrival of the Portuguese explorers and merchants, through the period of the era of British imperialism and colonisation and onto the contemporary era of petroleum resources development operations in the Kingdom and other oil-rich Kingdoms and ethnic nationalities and communities of the oil-rich minority ethnic Niger Delta region and other oil producing areas of Nigeria. During the era of British imperialism and eventual colonisation, the Royal Niger Company played a prominent role to foster British rule in the delta region and other parts of pre-colonial Nigeria, with which the British authorities established direct relations. ${ }^{4}$ The Kingdom plays host to giant MNOCs such as Shell Nigeria (the Shell Petroleum Development Company of Nigeria Limited [SPDC]), Mobil Producing Nigeria Unlimited (MPNU, a subsidiary of Exxon Mobil incorporation), Nigeria LNG Limited (NLNG), and Chevron Nigeria Limited, including sub-contracting multinational and Nigerian oil and gas firms and other allied businesses. These giant MNOCs operating in Bonny Kingdom are constituted as the Bonny Joint Industry Companies (JICs). Various tiers of government, the Bonny JICs, other business organisations, the traditional authorities and entire houses and people of Bonny Kingdom are able to muster efforts to harmoniously develop the Kingdom, and thereby promote SCD thereof. ${ }^{5}$ By and large, SCD in Bonny Kingdom requires GSR, embedded in GTG and CSR. SCD in Kingdom also depends on government social responsibility (GSR), which includes traditional government social responsibility (TGSR), Corporate Social Responsibility (CSR) and Community Social Responsibility (SRC: i.e., social responsibilities of Bonny people, communities and houses), championed by social responsibility of traditional rulers of the Kingdom (TGSR). ${ }^{6}$

${ }^{1}$ G. A. Oguntade, 'The Social Contract: Which Way Nigeria?' < https://thenationonlineng.net/social-contract-way-nigeria/> Accessed 27 March, 2020

${ }^{2}$ Holy Bible, Proverbs 16:12 and Proverbs 14:34 (b); Proverbs 16:12 provides that it is an abomination for Kings [rulers] to commit wickedness: for the throne is established by righteousness', while Proverbs 14:34 (b), provides that 'righteousness exalts a nation'.

${ }^{3}$ E. T. Bristol-Alagbariya (2010 [n7]).

${ }^{4}$ M. Crowder, The Story of Nigeria (Faber and Faber 1978), 152-170; E. J. Alagoa and A. A. Derefaka (eds) (n23), 282; N. Wariboko, Pattern of Institutions in the Niger Delta (Onyoma Research Publications 2007), 129, 229, 243-244 and 287; Encyclopaedia Britannica, 'Royal Niger Company' $<$ https://www.britannica.com/topic/Royal-Niger-Company $>$ Accessed 27 March, 2020.

${ }^{5}$ Goal 17 UNSDGs, captioned 'Partnerships for the Goals' so as to strengthen the means of implementation and revitalise the Global Partnership for Sustainable Development; UN, 'Sustainable Development Goals: About the Sustainable Development Goals' <https://www.un.org/sustainabledevelopment/sustainable-development-goals/> Accessed 27 March, 2020; J. Nelson, Partnerships for Sustainable Development: Collective Action by Business, Governments and Civil Society to Achieve Scale and Transform Markets (Commissioned by the Business and Sustainable Development Commission 2017); W. N. Raditloaneng and M. Chawaw, Lifelong Learning for Poverty Eradication (Springer International Publishing 2015), especially 241-254; United States Environmental Protection Agency (USEPA), 'Partnership for Sustainable Communities: Supporting Environmental Justice and Equitable Development' $<$ https://www.epa.gov/smartgrowth/partnership-sustainable-communitiessupporting-environmental-justice-and-equitable> Accessed 27 March, 2020; R. Phillips et al, Sustainable Communities: Creating a Durable Local Economy (Routledge 2013); M. Roseland, Toward Sustainable Communities: Solutions for Citizens and Their Governments (New Society Publishers 2012); M. Raco, Building Sustainable Communities: Spatial Policy and Labour Mobility in Post-war Britain (Policy Press 2007); A. Friedman, Designing Sustainable Communities (Bloomsbury Visual Arts 2017); T. M. Ebiede, Community Development and Poverty Reduction: A Case Study of Rural Communities in Bayelsa State, Nigeria (LAP LAMBERT Academic Publishing 2011); H. Barton (ed), Sustainable Communities: The Potential for Eco-neighbourhoods (Earthscan 2000).

${ }^{6}$ D. Adeojo, 'Bridging the gap between the government and the governed' < https://www.thecable.ng/bridging-gapgovernment-governed $>$ Accessed 27 March, 2020; E. T. Bristol-Alagbariya (2010 [n7]), 12-14, 28, 38-39, 326-327 and 330- 


\section{Conclusion}

This study represents a concise history of the natural law-oriented bedrock of traditional leadership and primordial society of oil-rich Niger Delta region's Ancient Grand Bonny Kingdom, otherwise known as the Ancient Ibani nation (Ibanise), established by the Founding Ancestors of the Kingdom before or about AD 1,000. It discusses the Kingdom, simply called Bonny Kingdom, as a significant symbol of a primordial civilisation of Ancient Niger Delta region and Africa at large. It highlights that the Kingdom was the economic and political centre of the Ancient Niger Delta region and a significant symbol of African civilisation, before the creation of Opobo Kingdom out of it (in 1870) and the eventual evolution of modern Nigeria (in 1914). It discusses the ward, lineage or house system as the core social system and pivot of life and society in Ancient Grand Bonny Kingdom and its sister Ancient Niger Delta City and Trading States of Elem Kalabari (New Calabar), Okrika and Nembe (Brass) as well as the Efik City and Trading State of Old Calabar and the Itsekiri (Warri) Trading Kingdom of Western Niger Delta. It traces the origin of the house system, commonwealth and entire civilisation of Ancient Grand Bonny Kingdom, to the Founding Ancestors of the Kingdom, led by its Founding Fathers, Patriarchs and Aboriginal Monarchs, who established the public sector governance (which is now limited to traditional rulership) at the apex of which is kingship (Amanyanaboship).

The study demonstrates that public sector governance was originated at the beginning of the Kingdom, within the rubrics of the house system, by the Founding Ancestors (led by the Founding Fathers, Patriarchs and Premier Monarchs of the Kingdom, namely Kings Ndoli-Okpara, Opuamakuba, Alagbariye (Alagbariya) and Asimini. It establishes that although the Kingdom's form of governance is hierarchical, during the era of the Founding Ancestors decision-making and decision-implementation processes were characteristically harmonious, cordial, consensual and collective between and among the homogeneous Founding Kindred Group. This form of governance continued up to the era of King Halliday-Awusa. The study indicates that Bonny Kingdom lost its natural sovereign status and essence as a primordial African civilisation as a result of British imperialism over the Kingdom, other Kingdoms of Ancient Niger Delta and the rest of the ethnic nationalities and areas that made up pre-colonial Nigeria, which ultimately gave birth to modern Nigeria in 1914.

The study highlights that the Ibani word, Amanyanabo, means 'owner of the land (and entire territories in Bonny Kingdom'); nevertheless, those who so divinely, directly and collectively own the Kingdom are its entire Founding Ancestors, led by the Patriarchs and Premier Monarchs of the Kingdom. Consequently, the successors of the Premier Monarchs are not the actual owners of the Kingdom, but successors-in-office and/or title, who are beneficiaries of kingship, as a matter of natural law and natural right to leadership (being blood descendants of the Founding Ancestors). The natural right to leadership of successive Monarchs is the same as the right to leadership of other blood descendants of the Founding Ancestors, all of whom (as Asemes) are the Kingdom's 'nobles of aristocratic descent'.

This study also explains that the Ibani word Aseme is a natural (God-given) hereditary status of any Ibani individual, who is royal from birth. Hence, the Founding Ancestors of Ancient Grand Bonny Kingdom (Ancient Ibani nation) are the first Asemes, followed by their blood descendants.

Given that the term Aseme is associated with rulership of the Kingdom, it (Aseme) is a title and status of 'aristocratic-nobility'. An Aseme could be an Asemebo ('person of aristocratic-nobility or aristocratic-birth') or distinctively Aseme-Owibo (Aseme-Owutuwo: 'man of aristocratic-nobility or aristocratic-descent') or AsemeOrubo ('woman of aristocratic-nobility or aristocratic-birth') in the Kingdom. In all ramifications, Aseme is a time immemorial status and title of the Founding Ancestors of the Kingdom and their blood descendants as well as the houses of these Ancestors and their blood descendants. It (Aseme) is a natural law and thus inalienable royal status protected by God divine's inheritance law, natural law, its associated natural right to succession and inheritance, as well as human rights law. In other words, the inalienable royal status of the Asemes and Aseme-waris of Bonny Kingdom is matter of God's given birth right, which makes it a subject-matter of natural law, natural right to succession and inheritance as well as human rights law, by virtue of divine providence that Asemes are blood descendants of the Founding Ancestors, particularly the Founding Fathers, Patriarchs and Premier Monarchs of the Kingdom.

As apex traditional rulers, Asemes become either Aseme-Alapu (Amadapu, Paramount Heads [Chiefs] of Duawaris) or Amanyanapu (Monarchs) of the Kingdom. The title Aseme-Alabo is same as Aseme-Se-Alabo and AsemeAmadabo, as these three titles may refer to the Head or Paramount Chief of a Duawari. However, Asemes who are heads of minor blood descendant houses of the Founding Ancestors are not Amadapu. So far, in the history of the Kingdom, only Asemes could be and have been Paramount Heads of Duawaris (Amadapu) and Monarchs (Amanyanapu). Kingship (the Monarchy) of Bonny Kingdom has from time immemorial to the contemporary era 
of the Kingdom been steadily sustained among the Asemes of Duawaris extraction, even in the continuing era of blood descendants of King Perekule, based on the prevailing form of succession to the position of Kingship in the Kingdom. By and large, given that each of the Duawaris, which include the Perekule royal house, is Aseme-wari, its head bears the title (Aseme-Alabo) royal. Based on the human right and fundamental freedom of peaceful assembly and association, the association of Duawaris (Founding and Aboriginal royal houses) of Ancient Grand Bonny Kingdom is the umbrella organisation of Major Aseme-waris ('main houses of Asemes' ['houses/families of aboriginal royal status') of the Kingdom. However, in the ongoing modern era, the head of the Perekule royal house, who would become the Monarch is stylishly called Amanyanabo-elect. Nevertheless, from time immemorial, Paramount Heads of Duawaris have usually been selected and not elected. As explained in the main analysis of the study, Duawaris of Bonny Kingdom are the Perekule royal house and five others, which are simply, precisely and squarely the houses of senior cousins and uncles of King Perekule. On the whole, Duawaris of Bonny Kingdom are the lineages or houses of the Founding Ancestors and Major houses of blood descendants of the Founding Ancestors, among which is blood descendant stock of King Fubara Manila Pepple (known as the contemporary Perekule royal house). From our examination and of analysis of natural law and its component natural right to succession, Aseme-waris, whether Duawaris or minor houses of Duawaris are natural royal houses, the sole determining factor being God's divine direct-blood descent from the Founding Ancestors, especially the Founding Fathers, Patriarchs and Premier Monarchs of the Kingdom. While, the Duawaris are Opu Aseme-waris (major and aboriginal royal houses), the Kala Aseme-waris are minor royal houses of the Kingdom.

The fact that an Aseme is chosen or otherwise emerges as a Paramount Chief of a Duawari and therefore occupies the traditional rank of Amadaboship or a Monarch (Amanyanabo), does not mean that such an Aseme has a superior birth right or an exclusive right under natural law than other Asemes. So, by virtue of natural right to leadership founded on natural law, all Asemes have the same inalienable natural right to the two apex traditional leadership positions Amadaboship and Amanyaboship. However, principally, there can be only one Monarch at a time as well as one Paramount Head of the rest of the Duawaris. The Monarchs and Paramount Heads of each of the Duawaris should therefore consider themselves more as occupying privileged positions, indeed God's divine privileged positions, than their consanguineal relatives, who are also blood descendants of the Founding Ancestors. Hence, the Monarchs and Paramount Heads of the rest of the Duawaris should promote and sustain the age-long wellestablished norm and practice of TGSR embedded in GTG, bequeathed by their blood Ancestors (the Founding Ancestors of the Kingdom).

It is of public knowledge that good leaders and rulers listen to the voice or voices of reason, to establish, promote and enforce truth and fair-play in society. Also, it is an inherent conditionality of natural law that leadership positions are for public good, and not otherwise. Accordingly, it is well-established in Christendom that God Almighty selects and anoints leaders. Therefore, each apex traditional ruler of oil-rich and Christianised Bonny Kingdom, be it an Amanyanabo, Amadabo or Se-Alabo, should at least endeavour to be a good leader of responsible stewardship to the people and entire Kingdom. Leaders of the Kingdom should, at least, rule to please and/or satisfy the Almighty, Who is the Maker, Principal and thus Foremost Examiner as well as the Chief Executive, General Overseer and hence Ultimate Watchman of all leaders (including Monarchs) and governments in all places and societies around the world.

So far, this study has demonstrated how Premier Kings Alagbariya and Asimini ruled primordial Bonny Kingdom by rendering yet unparalleled selfless leadership based on responsible service to the people and the entire Kingdom. During their reign, they exhibited natural law features of love, goodwill, selflessness, benevolence, transparency, accountability and such other as moral (ethical) norms of fair-play, humility and commitment to duty, among others. They made incomparable personal, supreme, painful and overwhelming sacrifices towards the wellbeing of the people and the entire Bonny Kingdom. As classical examples of exceptional and incomparable public-spiritedness, they offered the blood of their own daughters for the good and wellbeing of Bonny Kingdom. Even while exercising their natural right of rulership, Premier Kings Alagbariya and Asimini voluntarily offered their daughters, Aboriginal Virgin Crown Princess Osunju Alagbariya and Virgin Crown Princess Ogbolo Asimini, as 'sacrificial lambs' to the deities of the land and sea, for the peace, development, growth, survival and sustenance of Bonny Kingdom and by extension modern Nigeria at large. Also, in the course of their reign as Monarchs, Alagbariya and Asimini listened to the voice or voices or reason by involving and engaging the rest of the founding blood-related kindred group in decision-making and decision-implementation processes, such that governance at the time was characteristically harmonious between and among the founding kindred group of the Kingdom.

The characteristic features of traditional government social responsibility (TGSR) per excellence, towards overall public good, underlined the reign and administration of the entire four Founding Fathers, Patriarchs and Premier Monarchs of the Kingdom, namely Ndoli-Okpara, Opuamakuba, Alagbariya and Asimini. This form of good 
traditional leadership (good governance [GG]) was imbibed by the immediate blood descendants and successors of the Premier Monarchs, as exemplified during the reign of King Halliday-Awusa, by King Halliday-Awusa himself and other members of the apex ruling class of the Kingdom. The same selfless and public-spirited form of leadership of the Founding Ancestors, Premier Monarchs and predecessors, made King Halliday-Awusa to entrust kingship on his cousin, Perekule.

The Premier Monarchs of Bonny Kingdom, along with the rest of the Founding Ancestors of the Kingdom, who established civilisation, which includes the house system of governance, Commonwealth and entire heritage of the Kingdom, established the doctrine and practise of selflessness, based on responsible stewardship, in public administration, which is rooted in natural law. They fostered, promoted and practised the relationship of natural law to their natural right to leadership, based on selfless public service directed towards overall wellbeing of the people and the entire Kingdom. So, GTG in Bonny Kingdom, dating back to the era of the Premier Monarchs of the Kingdom, may be described as is rooted in natural law and thus the intertwined relationship of natural law, natural rights to leadership and selfless public service (responsible stewardship), is crucial and inevitable, in the ongoing era of sustainable development (SD) and world-wide yearning for GG, towards human wellbeing and overall wellbeing of society, as the entire world is increasingly becoming a global village, more than ever before in the history of world civilisation.

Therefore, the landmarks and lessons of GTG established by Ndoli-Okpara, Opuamakuba, Alagbariya and Asimini, and thereafter sustained up to the era of King Halliday-Awusa, in the form of selfless leadership, are for succeeding Monarchs and country chiefs, as apex traditional rulers, to preserve, defend and continue to uphold the legacies of good leadership bequeathed by the Monarchs of the Kingdom considered in this study. Succeeding apex traditional rulers of the kingdom, should, as individuals and as a group, concentrate on conscientiously and assiduously working towards the advancement, progress and general wellbeing of the people and houses of the Kingdom and the all-inclusive prosperity of the entire kingdom itself. Alongside the God-given strategic location of oil-rich Ancient Grand Bonny Kingdom, taking cognizance of the significance of the house system as the core social system and pivot of life and society at large in the Kingdom as well as the key role of traditional government in the Kingdom, successive Monarchs (Amanyanapu) and Country Chiefs (Se-Alapu), as apex traditional rulers, as well as the houses and entire people of Bonny, should exhibit the exemplary attributes and practices of GTG bequeathed to them by their early traditional rulers.

We emphasise that the Founding Ancestors of oil-rich primordial Grand Bonny Kingdom, led by the Kingdom's four Premier Monarchs, who God Almighty directly bestowed the Kingdom upon as a heritage, were not Christians, but knew God Almighty ('The Creator of Heaven and Earth': Sonakirinateme Tamuno, as the Ultimate Supreme Being). These Ancestors, who established the Kingdom's civilisation, laid a landmark foundation on how the Kingdom should be governed on the basis of GTG established on divinely-based natural law and its accompanying natural right, integrity and responsible stewardship to the people (TGSR) Accordingly, the Founding Ancestors established an exemplary manner of how the people and lineages (families or houses) of the Kingdom should relate between and among themselves on the premises of voice or voices of reason, truth, fair-play and due process, which are characteristic features of natural law. Succeeding generations of the Kingdom, led by succeeding Monarchs and other members and organs of the apex traditional ruling council, should thus follow such exemplary qualities and manner of relating with each other, while living and inheriting from oil-rich the Kingdom, towards GTG and SCD in the Kingdom.

The traditional rulers of oil-rich Christian Bonny Kingdom should be committed to the social contract of governance and GSR, ingrained in GG, which apply to all forms of government, including traditional governments (traditional rulership), and these should sensitise and persuade successive traditional rulers of the Kingdom, especially Monarchs (Amanyanapu) and Country Chiefs (Se-Alapu), to imbibe and practise the GTG, based on TGSR in the Kingdom, towards GTG and SCD in the Kingdom. TGSR, inherent in GTG and equipped with other characteristic features of GG, constitutes a collective road-map to good, more rational and robust administration, management and utilisation of the commonwealth and entire heritage of the oil-rich Kingdom, in the overall interest of its people, communities and country houses. In particular, succeeding apex traditional rulers of the Kingdom should promote natural law-oriented attributes of TGSR, and should neither collectively or otherwise, violate the rule of law nor abuse human rights of citizens, particularly the fundamental rights of their colleagues. Apex traditional rulers of the Kingdom should respect, uphold and practise natural law-oriented attributes of TGSR, ingrained in selfless public service, responsible stewardship and integrity, so as to promote and achieve overall wellbeing of the people, communities and houses of oil-rich Bonny Kingdom.

Finally therefore, it behoves on any incumbent Monarch to administer GG, through TGSR, while legitimately 
enjoying the position of kingship as a blood descendant of the Founding Ancestors. Hence, from the base and bedrock of divinely-rooted natural law and the realisation of natural right to kingship, the one and only key issue is for an incumbent of the throne of kingship to conscientiously advocate, boost and practise TGSR ingrained in GTG, and nothing more, towards all-embracing advancement, prosperity and SCD of oil-rich and Christianised Bonny Kingdom, in the ongoing worldwide era of globalisation, especially economic globalisation, GG and SD.

\section{References}

Abam A. S., King Ibanichuka (Ado VI) 1816 - 1896: The Last of Okrika's Sovereign Rulers (Samag Stationery 2014 ), 1.

Abbey K. I., Spot Light on Grand Bonny (K. I. Abbey, 1991), 1 and 16-17.

Achebe C., The Trouble with Nigeria (Fourth Dimension 1983) particularly 1-3.

Achebe C., There Was A Country: A Personal History of Biafra (Penguin Group 2012).

Alford C. F., Narrative, Nature, and the Natural Law: From Aquinas to International Human Rights (Palgrave Macmillan 2010).

Alagoa E. J., A History of the Niger Delta (Onyoma Research Publications 2005), 151-152.

Alagoa E. J., 'Long-Distance Trade and States in the Niger Delta' [1970] 11 (3), The Journal of African History, 319-329.

Alagoa E. J. and Derefaka A. A. (eds), The Land and People of Rivers State: Eastern Niger Delta (Onyoma Research Publications 2002), 7 and 324-326.

Alagoa E. J. and Fombo A., A Chronicle of Grand Bonny (Ibadan University Press 1972/Onyoma Research Publications 2001), vii-viii, 3-10, 13-15, 17, 24-27, 41, 45-46, 49, 54-67, 73, 75, 76 and 89.

Alagoa E. J., Tamuno T. N. and Clark J. P. (eds), The Izon of the Niger Delta (Onyoma Research Publications 2009), 262-263.

Anderson M. G. and Peek P. M. (eds), Ways of the Rivers: Arts and Environment of the Niger Delta (Regents of the University of California 2002), 251-267.

Anene J. C., Southern Nigeria in Transition 1885-1906: Theory and Practice in a Colonial Protectorate (Cambridge University Press 2009).

Ashdown D., The Royal Line of Succession: The British Monarchy from Egbert AD 802 to Queen Elizabeth II (Pitkin Publishing 1999).

Barton H. (ed), Sustainable Communities: The Potential for Eco-neighbourhoods (Earthscan 2000).

Berry R. J., Inheritance and Natural History (William Collins 2013).

Bonny Chiefs' Council/Amanyanabo-in-Council of Bonny Kingdom, 'Farewell Ceremonies for His Royal Majesty, Captain Opuada Secondus Pepple, King Perekule II, Amanyanabo of Bonny [1996] Bonny Chiefs' Council/Amanyanabo-inCouncil of Bonny Kingdom, 4.

Bonny Kingdom Historical Society, The History of Bonny (Bonny Kingdom Historical Society 2011), 20, 49-50 and 53-54.

Borkowski J. A., Textbook on Succession (Oxford University 2005).

Breshears J. D., Natural Law: The Moral Foundation for Social and Political Civility (CentrePointe Publishing 2016).

Briggs N., Okowa W. and Ndimele O. (eds), The Economic Development of Rivers State: In Commemoration of Port Harcourt Celebration 2013 (Onyoma Research Publications 2013), 50-85.

Bristol-Alagbariya E. T., Governance Towards Sustainable Development in Nigeria: The Role of Strategic Assessment of Decisions \& Actions (Centre for Energy, Petroleum \& Mineral Law \& Policy [CEPMLP]/Dundee University Press [DUP] 2013), 101-104, 251 and 261.

Bristol-Alagbariya E. T., Participation in Petroleum Development: Towards Sustainable Community Development in the Niger Delta ([CEPMLP]/ DUP 2010), xxxiii, 12-14, 24, 26-28, 38-39, 31, 43, 101-103, 105-126, 112-115, 117-118, 124, $130,134,137,326-327$ and 330-335.

Bristol-Alagbarigha royal house (Founder of Grand Bonny) v The Shell Petroleum Development Company of Nigeria Ltd (SPDC), Suit No. PHC/399m/2002, Consent Judgment given on 9 June, 2010, by the Hon. Justice Ben E. Ugbari (Unreported).

Bristol-Alagbarigha royal house (Founder of Grand Bonny) v Nigeria LNG Limited, Suit No. PHC/573/2011, Consent Judgment given on 30 April, 2012, by the Hon. Justice T. A. Oji.

Budziszewski J., Written on the Heart: The Case for Natural Law (InterVarsity Press 1997).

Buowari O. Y., The People and Culture of Grand Bonny Kingdom: The Ibani Cultural Heritage (Masterpiece Resources 2014), 3-4, 7-13, 18-19, 65, 71, 120-121, 124-127, 139, 149, 162, 165, 170-171, 189, and 191.

Carr E. H., What is History?; His Acclaimed Reflections on the Theory of History and the Role of the Historian (Penguin Books 1984).

Charles River Editors, The Scramble for Africa: The History and Legacy of the Colonization of Africa by European Nations during the New Imperialism Era (Charles River Editors 2017).

Chief Abusi Green v Chief Dr E. T. Earnest Green (SC.206/1986).

Chief Samuel O. Tobin \& 2 Ors (For Themselves and For and On Behalf of the Members of Tobin House) $v$ Chief Israel I. Brown \& 3 Ors (For Themselves and For and On Behalf of the Members of Buoye Omuso Brown House (Suit No. PHC/174/72 [2010] 9 Rivers State Law Report, 92-102.

Crow H., Memoirs of the Late Captain Hugh Crow of Liverpool: The Life and Times of a Slave Trade Captain (Bodleian Library/Oxford University Press 2007), 95.

Crowder M., The Story of Nigeria (Faber and Faber 1978), 152-170, 188-206.

Dike K. O., Trade and Politics in the Niger Delta 1830-1885: An Introduction to the Economic and Political History of Nigeria (Greenwood Press 1981), 24, 31-32 and 196.

Ebegbulem J. C., Ekpe D. and Adejumo T. O., 'Oil Exploration and Poverty in the Niger Delta Region of Nigeria: A Critical 
Analysis' [2013] 4 (3) International Journal of Business and Social Science, 280.

Ebiede T. M., Community Development and Poverty Reduction: A Case Study of Rural Communities in Bayelsa State, Nigeria (LAP LAMBERT Academic Publishing 2011).

Clarke J. D., Yakubu Gowon: Faith in United Nigeria: Faith in a United Nigeria (Frank Cass and Company 1987).

Ejituwu N. C., A History of Obolo (Andoni) in the Niger Delta (Mason Publishing Co. 1991), 112-123 and 257-261.

Ennals C. T. C. (Assistant District Officer), 'Government of the Federal Republic of Nigeria, Intelligence Report on the Ndoki Clan of Aba Division' [Marked File No. EP 10298], paragraph 24, 9.

Federal Ministry of Education, 'Government of the Federal Republic of Nigeria, 'Synopsis of the Reigns of the Monarchs of the Kingdom of Grand Bonny (AD 1200 - 1878)' [National Archives Marked File No. CALPROF 5/3].

Federal Republic of Nigeria, Nigeria at 50: A Compendium: The Official and Authoritative Book about Nigeria (Published on the Golden Jubilee

Friedman A., Designing Sustainable Communities (Bloomsbury Visual Arts 2017).

Gomez-Lobo A., Morality and the Human Goods: An Introduction to Natural Law Ethics (Georgetown University Press 2001).

Government of the Federal Republic of Nigeria, Intelligence Report on Bonny District, Owerri Province [1960] MINOG, marked File No. EP 8691, 6/1/60, paragraphs 17-19, 7.

Greenleaf R. K. and Spears L. C. (eds), Servant Leadership: A Journey into the Nature of Legitimate Power and Greatness 25th Anniversary (Paulist Press 2002).

Independence Anniversary www.1stoctober.com Publishing 2010), 26-28, 33.

Finapiri G., Forgotten Heroes of Grand Bonny (CSS Press 2001) v, 7-9.

Finnis J., Natural Law \& Natural Rights (Oxford University Press 2011).

Fombo Hart C. T. O, Aspects of Bonny in Perspective (Soteria Publishing House 2014), 2-7.

Forster S., Mommsen W. J. and Robinson R. (eds), Bismarck, Europe and Africa: The Berlin Africa Conference, 1884-85, and the Onset of Partition (Oxford University Press 1989).

Jaja J. M., 'The Nembe Coup of the Academics: A Historical Account of the 1995 Chieftaincy Fiesta' [2007] 9 (2) Sophia: An African Journal of Philosophy and Public Affairs, 31-36.

James A., Sovereign Statehood: Basis of International Society (HarperCollins Publishers 1986).

Jones G. I., The Trading States of the Oil Rivers: A Study of Political Development in Eastern Nigeria (Oxford University Press 1963/James Currey Publishers 2000), 18, 51, 55-56, 61-62, , 110, 128, 161, 172, 174, 176, 198, 202 and 243-245.

Ikime O., Niger Delta Rivalry: Itsekiri Urhobo Relations and the European Presence, 1884-1936 (Longman 1970).

Imoagene O., Peoples of the Cross River Valley and Eastern Delta: Know Your Country Series Handbook of Nigeria's Major Culture Areas (New Era Publishers 1990), 26 and 50.

Kerridge R., Parry and Kerridge: The Law of Succession (Sweet \& Maxwell 2016).

Klug F., A Magna Carta for All Humanity: Homing in on Human Rights (Routledge 2015).

Kramer M. H., Where Law and Morality Meet (Oxford University Press 2004).

Leonard M. A. G., The Lower Niger and Its Tribes (Frank Cass \& Co. 1968) 23-24 and 47.

Lama D., The Little Book Of Wisdom (Rider 2000).

Lincoln A., Leadership Lessons of Abraham Lincoln: Strategies, Advice, and Words of Wisdom on Leadership, Responsibility, and Power (Skyhorse Publishing 2011).

Lugard F. J., 'Lugard in Nigeria: Report on the Amalgamation of Northern and Southern Nigeria and Administration, $1912-$ 1919' (Unpublished Reports of Library of African Study: Routledge 2004).

Malemi E., The Nigerian Constitutional Law (Princeton Publishing Co. 2012), 84 and 284-315.

Nelson J., Partnerships for Sustainable Development: Collective Action by Business, Governments and Civil Society to Achieve Scale and Transform Markets (Commissioned by the Business and Sustainable Development Commission 2017).

Niger Delta Development Commission (NDDC), Niger Delta Regional Development Master Plan (NDDC 2006), 49-50, 5355 and $60-67$.

Northouse P. G., Leadership: Theory and Practice (SAGE Publications 2016).

Nweke K. and Nkwede J. O., 'The Nigerian State and Hobbes' Social Contract Theory: An Albatross around the Collective Will of the People' [2019] 152 (3) European Journal of Scientific Research, 304-321.

Obasanjo O., My Command: An Account of the Nigerian Civil War, 1967-1970 (Heinemann 1981).

Obuoforibo B. A., Topics in Bonny Church History (CSS Press 2001), 259.

Ogolo G. N. S., Opobo Excerpts (An Insight into An African Kingdom) (Etuk Concepts, 2012), 134.

Olomojobi Y., Human Rights and Civil Liberties in Nigeria: Discussions, Analyses, and Explanations (Princeton \& Associates Publishing Co. 2018), 2.

Orji K. E., 'The Place of Bonny in Niger Delta History' [2011] 5 (5) (22) African Research Review, 36 -45.

Osae T. A. and Nwabara S. N., A Short History of West Africa (London University Press 1968), 147.

Osae T. A., Nwabara S. N. and Odunsi A. T. O., A Short History of West Africa, A.D. 1000 to the Present (Hill and Wang 1973). Pakenham T., The Scramble for Africa (Abacus 1992/2003).

Peikoff L. (ed), The Voice of Reason: Essays in Objectivist Thought (Penguin Books 1990).

Pepple U. and Oko-Jaja T. (eds), Contemporary Historical Perspectives on Opobo (Volume One) (Opubowatch Publications 2015), 10.

Phillips R., Seifer B. F. and Antczak Ed., Sustainable Communities: Creating a Durable Local Economy (Routledge 2013).

Phillips D. T., Lincoln on Leadership: Executive Strategies for Tough Times (Warner 1992).

Poser N. S., Lord Mansfield: Justice in the Age of Reason (McGill-Queen's University Press 2013).

Programme of the $20^{\text {th }}$ Coronation Anniversary of His Majesty, Dr Edward Asimini William Dappa Pepple, III, CON, JP, Perekule XI, Natural Ruler and Amanyanabo of Grand Bonny Kingdom, 9 and 13.

Raditloaneng W. N. and Chawaw M., Lifelong Learning for Poverty Eradication (Springer International Publishing 2015), 
241-254.

Raco M., Building Sustainable Communities: Spatial Policy and Labour Mobility in Post-war Britain (Policy Press 2007). Rand A., The Voice of Reason: Essays in Objectivist Thought: 5 (Penguin 1990), 3-6.

Rice C. E., 50 Questions on the Natural Law: What It Is and Why We Need It (Ignatius Press 1999).

Robert G., Concise 48 Laws of Power (Profile Books 2002).

Roseland M., Toward Sustainable Communities: Solutions for Citizens and Their Governments (New Society Publishers 2012).

Sagay I., Nigerian Law of Succession: Principles, Cases, Statues and Commentaries (Malthouse Press 2006).

Shapiro B., The Right Side of History: How Reason and Moral Purpose Made the West Great (Broadside Books 2019).

Tierney B., The Idea of Natural Rights: Studies on Natural Rights, Natural Law, and Church Law 1150 - 1625 (Wm. B. Eerdmans Publishing 1997).

Ransome-Kuti v AG Federation [1985] Nigerian Weekly Law Reports (NWLR) (Part 60) 221, per Kayode Eso JSC.

Roosevelt C., The Science of Government, Founded On Natural Law (Nabu Press 2014).

Sachs J. F., The Age of Sustainable Development (University of Columbia Press 2015).

Sandefur T., 'In Defense of Substantive Due Process, or the Promise of Lawful Rule [2012] 35 (1) Harvard Journal of Law \& Public Policy, 284-326.

Sigmund P. E., Natural Law in Political Thought (University Press of America 1981).

Somerset v Stewart [1772] 98 ER, 499.

Smith B. C., Good Governance and Development (Palgrave Macmillan 2007).

Strauss L., Natural Right and History (Charles R. Walgreen Foundation Lectures) (University of Chicago Press 1965).

Tuck R., Natural Rights Theories: Their Origin and Development (Cambridge University Press 1998).

UN, Universal Declaration of Human Rights (UN 2018).

Waribere N. A. I., History of Finima, Bonny \& Her Chieftaincy Houses (Divine Printers \& Publishers Nig. 2008).

Wariboko N., Pattern of Institutions in the Niger Delta (Onyoma Research Publications 2007), 129, 229, 243-244 and 287.

Weir A., Britain's Royal Families: The Complete Genealogy (Vintage 2008).

Wise S. M., Though the Heavens May Fall: The Landmark Trial That Led to the End of Human Slavery (Da Capo Press 2006). Wren J. T. (ed), The Leader's Companion: Insights on Leadership Through the Ages (The Free Press 1995).

Yew L. K., From Third World to First: The Singapore Story - 1965-2000 (Singapore and the Asian Economic Boom) (HarperCollins Publishers 2000). 